\title{
Percepção dos turistas frente ao patrimônio histórico cultural: análise dos principais marcos religiosos de Tiradentes - MG a partir da Social Media Mining
}

\author{
Tourists perception of the cultural historical heritage: an analysis of the main religious brands of Tiradentes - MG \\ from the Social Media Mining \\ Percepción turística del patrimonio histórico cultural: análisis de los principales hitos religiosos en Tiradentes - MG \\ basado en Social Media Mining
}

Karine de Almeida Paula

Centro Universitário de Viçosa,, Brasil

karinealmeida.ufv@gmail.com

Teresa Cristina de Almeida Faria

Universidade Federal de Viçosa (UFV), Brasil

tcfaria.au@gmail.com
DOI: https://doi.org/10.18472/cvt.21n2.2021.1855 Redalyc: https://www.redalyc.org/articulo.oa? id $=115468015002$

Recepción: 31 Agosto 2020

Aprobación: 01 Junio 2021

\section{Resumo:}

O trabalho objetiva analisar a percepção dos turistas acerca dos principais marcos históricos religiosos da cidade de Tiradentes - MG, com o intuito de identificar a imagem perceptiva formada pelos mesmos a partir dos dados contidos na plataforma TripAdvisor. Em se tratando dos procedimentos metodológicos, foram analisados os dados obtidos junto ao TripAdvisor no período compreendido entre janeiro de 2012 a julho de 2020. Para obtenção e análise dos dados recorreu-se à técnica conhecida como Web Scraping (WS), utilizada em tarefas que envolvam mineração na web. A partir das técnicas empregadas, desenvolveuse nuvens de palavras, com representação de frequência de textos. Com base nas análises foi possível observar diferentes formas de percepção para os diferentes marcos religiosos da cidade, sendo que, em alguns momentos, a arquitetura presente nas edificações não apresentou expressividade singular, sendo substituída por elementos temporais, históricos e externalidades vizinhas.

Palavras-chave: Paisagem urbana, Patrimônio Histórico Religioso, Data Science, Tiradentes - MG.

\section{AbStract:}

The work aims to analyze the perception of tourists about the main religious historical landmarks in the city of Tiradentes - MG, to identify the perceptual image formed by them from the data contained in the TripAdvisor platform. In terms of methodological procedures, were analysis of data obtained from TripAdvisor between january 2012 and july 2020. To obtain and analyze the data, we used the technique known as Web Scraping (WS), used in tasks that involve mining on the web. From the techniques employed, word clouds were developed, with representation of text frequency. Based on the analysis, it was possible to observe different forms of perception for the different religious landmarks of the city, and at times, the architecture present in the buildings did not show singular expressiveness, being replaced by temporal, historical elements and neighboring externalities.

KEYWORDS: Urban landscape, Religious Historical Heritage, Data Science, Tiradentes - MG.

\section{ReSUMEN:}

El trabajo tuvo como objetivo analizar la percepción de los turistas sobre los principales hitos históricos religiosos de la ciudad de Tiradentes - MG, con el fin de identificar la imagen perceptual formada por ellos a partir de los datos contenidos en la plataforma TripAdvisor. En el caso de los procedimientos metodológicos fueron análisis de datos obtenidos de TripAdvisor en el período de enero de 2012 a julio de 2020. Para la obtención y análisis de los datos se utilizó la técnica conocida como Web Scraping (WS), empleada en tareas de minería en la web. A partir de las técnicas empleadas se desarrollaron nubes de palabras, con representación de la frecuencia del texto. A partir de los análisis, fue posible observar diferentes formas de percepción de los diferentes hitos religiosos de la ciudad y, en ocasiones, la arquitectura presente en los edificios no mostró una expresividad singular, siendo reemplazada por elementos temporales, históricos y externalidades vecinas.

Palabras Clave: Paisaje urbano, Patrimonio histórico religioso, Ciencia de los datos, Tiradentes - MG. 


\section{INTRODUÇÃO}

A percepção acerca da paisagem urbana perpassa por uma interação do homem com o lugar, promovendo assim, experiências individuais que se colocam em relação direta com sentimentos e memórias. A paisagem urbana, por Cullen (2015), é colocada, de uma forma geral, como um resultado do acúmulo de tempos das ações e intervenções no espaço urbano, carregando consigo elementos e signos decorrentes de distintos tempos e modos de viver. Estes variados tempos sobrepostos na paisagem, por sua vez, alcançam na atividade turística a possibilidade de serem consumidas a um só tempo e ritmo.

Neste contexto, em tempos onde a quantidade e diversidade de informações sobre as cidades são cada vez maiores, é relevante destacar a importância de ferramentas que auxiliem no alcance de leituras cada vez mais reais da cidade e sua paisagem, principalmente cidades turísticas, como bem coloca Gali e Donaire (2013), ao afirmarem a importância e o surgimento de novas metodologias para se estudar o comportamento real do turismo. Dessa maneira, tendo em vista a potencialidade na geração de dados por parte das tecnologias informacionais atualmente, destaca-se o uso das mídias sociais como ferramenta na geração de dados, e por conseguinte, de informação.

À vista disso, o artigo teve como objetivo analisar qual seria a percepção dos turistas acerca dos principais marcos religiosos da cidade de Tiradentes, Minas Gerais, identificando a imagem perceptiva formada pelos mesmos a partir dos dados abertos contidos nas mídias sociais, mais especificamente, na plataforma do TripAdvisor. O lócus da pesquisa se apresenta como uma cidade histórica e turística, datada do período colonial brasileiro, de pequeno porte demográfico e localizada no Campo das Vertentes, no estado de Minas Gerais.

As mídias sociais podem ser caracterizadas por plataformas digitais nas quais existem distintas possibilidades de interação e participação entre os usuários, possibilitada pela popularização e acesso à Internet. A escolha pela plataformaTripAdvisor se deu tendo em vista o fluxo turístico recebido na cidade e também pela tipologia dos dados contidos na plataforma, que se configura como um site de viagens, oferecendo uma interação e compartilhamento de experiências e opiniões entre os turistas.

Dessa maneira, é preciso caracterizar quais dados seriam possíveis coletar ao referir-se aos estudos que apresentem como banco de dados as mídias sociais. De acordo com Davidowitz (2018, p. 97), os dados coletados, via web, se caracterizariam pelo formato de textos - palavras - e imagéticos - fotos. Logo, infere-se que as fotografias, imagens e textos em si são representações, se reportando a um olhar sobre o objeto. Alguns autores já vêm se debruçando em estudos recentes envolvendo a produção de dados nas mídias sociais e o uso dos mesmos em pesquisas, tais como os trabalhos de Thomaz, Biz, Bettoni e Mendes Filho (2016), que propuseram um estudo de metodologia de mineração de conteúdos de mídias sociais (Twitter), com o intuito de auxiliar a gestão de destinos turísticos. O trabalho de Severo (2019) nas ciências sociais, cujo objetivo é inserir dados abertos (web) em pesquisas que envolvam a construção do patrimônio cultural na web, assim como, representações digitais de espaço e lugar mediante dados do Twitter.

De forma contextual, o trabalho se justifica dada as novas possibilidades colocadas ao planejamento e gestão urbana e turística diante dos estudos ligados à Data Science e a Social Media Mining. Os estudos e o desenvolvimento dessas técnicas estão ancorados nos conceitos de mineração de mídia social, representando um campo de extração, análise e reconhecimento de padrões de dados de mídias sociais (Zafarani, Abbasi \& Liu, 2014).

Já na escala de Tiradentes, o trabalho se coloca como relevante à medida que ilustra novas formas de se abordar o turismo em cidades, sobretudo, cidades pequenas e patrimoniais. O estudo do patrimônio e sua percepção por meio de dados digitais, pode contribuir em políticas voltadas à gestão turística, sobretudo. Conhecer o comportamento dos visitantes em um destino permite viabilizar e melhorar a gestão turística dos espaços. 
Neste contexto, duas questões problemas são colocadas pelo artigo, sendo elas: De que maneira os comentários contidos na plataforma do TripAdvisor revelariam uma imagem percebida e projetada acerca dos marcos religiosos de Tiradentes? De que maneira as ferramentas de social media mining e os dados contidos nas mídias sociais poderiam auxiliar nos estudos a respeito da percepção turística?

\section{PROCEDIMENTOS METODOLÓGICOS}

$\mathrm{O}$ artigo se classifica a partir de uma abordagem qualitativa de caráter exploratória e descritiva. A metodologia centrou-se na obtenção e análise de dados obtidos junto ao TripAdvisor ${ }^{[1]}$ no período de janeiro de 2012 a julho de 2020. A definição do período dos dados do TripAdvisor, 8 anos praticamente, se dá em função de abranger um maior número de dados, essencial para análises envolvendo Big Data e definição de padrões por parte do software.

A coleta de dados na plataforma foi considerada como uma pesquisa de campo em uma comunidade virtual contendo dados abertos. Ao acessar a plataforma, foi selecionada a aba "Igrejas Tiradentes" e a escolha se justifica por conter várias subseções referentes ao patrimônio histórico religioso presentes na cidade.

Dessa maneira, foram eleitos os seguintes marcos: Igreja Matriz de Santo Antônio (3943 avaliações), Santuário da Santíssima Trindade (130 avaliações), Igreja Nossa Senhora do Rosário dos Pretos (750 avaliações), Igreja São João Evangelista (90 avaliações), Capela do Bom Jesus da Pobreza (11 avaliações), Capela Nossa Senhora das Mercês (206 avaliações), Capela Santo Antônio da Canjica (46 avaliações), Capela São Francisco de Paula (245 avaliações) - totalizando 5421 comentários.

Como é possível notar, o universo de comentários selecionados foi relativamente extenso, sendo relevante o uso de uma ferramenta computacional para auxiliar o processo de captura, organização e análise dos dados. O volume de textos é significativo e sua característica não estruturada aumenta as dificuldades de um procedimento totalmente manual. Deste modo, os dados textuais contidos nos comentários foram coletados através da técnica conhecida como Web Scraping (WS), referente a uma técnica de extração de dados utilizada para coletar dados de sites e tarefas que envolvem mineração na web. Para a extração dos dados brutos foi utilizado um programa desenvolvido na linguagem de programação Python, usando uma biblioteca específica denominada Beautiful Soup.

A etapa 1 consistiu na mineração dos dados disponíveis na plataforma do TripAdvisor e consistiu na importação do arquivo de texto no formato CSV, no carregamento dos dados e no pré-processamento na base de dados a partir da transformação e limpeza do texto. Neste momento, ocorre a substituição dos caracteres especiais do texto, a remoção de espaços em branco desnecessários, a conversão do texto em minúsculas e remoção de palavras irrelevantes, classificadas como stopwords. Foram suprimidos artigos, preposições, advérbios, favorecendo uma leitura mais clara da imagem gráfica e de modo a não obscurecer outros termos que possam ser relevantes. Em seguida ocorreu a construção do dataframe com a matriz de frequência das palavras. A frequência de determinadas categorias dentre as palavras analisadas se dá em função de sua repetição nos comentários extraídos. As palavras que mais se repetem se destacaram graficamente por meio do seu tamanho, fazendo com que seja possível observar as palavras mais representativas e utilizadas pelas pessoas ao postarem seus comentários.

Já na etapa 2, foram geradas as imagens gráficas a partir do pacote WordCloud. Essas imagens foram representadas pelas nuvens de palavras, geridas a partir da seleção das 50 palavras mais representativas para cada categoria elegida. $\mathrm{O}$ software permite que o usuário defina a quantidade de palavras a serem apresentadas na nuvem. Conforme destaca Amaral (2016, p. 70), as nuvens de palavras "[...] podem ser amplamente utilizadas em mineração de textos, exibindo termos mais frequentes em uma rede social ou utilizadas em análise de sentidos". Nas nuvens de palavras estão contidas as palavras mais representativas, que apresentam maior frequência, e quanto maior for a ocorrência de uma determinada palavra no texto, maior será o seu tamanho na nuvem. 
Foram observadas as palavras de maior destaque na nuvem em uma tentativa de correlacionar tais expressões, afinal de contas, uma palavra ao se repetir por diversas vezes pode estar sugerindo um padrão de discurso acerca do objeto analisado. Para a leitura e interpretação das informaçóes contidas na nuvem de palavras, recorreu-se a análise de conteúdo, com o intuito de identificar a imagem perceptiva a partir das falas presentes na plataforma. A análise de conteúdo se apresenta como um dos métodos mais usuais para exploração de um conjunto de dados textuais, tratando-se de "um conjunto de técnicas destinadas a estudar textos, imagens ou outros 'conteúdos', de modo a extrair destes, sistematicamente, algum tipo de sentido" (Recuero, 2018, p. 13).

Desse modo, foi aplicado, para a leitura e interpretação da nuvem de palavras, a técnica composta pela análise de conceitos, que nas palavras de Recuero (2018) se define como um componente mais simples e tradicional da análise de conteúdo, se dedicando, sobretudo, a obtenção de conceitos mediante os procedimentos de codificação e classificação dos dados. No que tange às análises referentes às impressões/ percepções dos turistas acerca do patrimônio religioso de Tiradentes, optou-se por ancorar-se nas discussóes realizadas por Lynch (1997) referente aos conceitos de imaginabilidade urbana e classificação da paisagem.

\section{O OLHAR DO TURISTA E AS MÍDIAS SOCIAIS: A CONSTRUÇÃO DA NARRATIVA DIGITAL}

O turismo, nas palavras de Gastal (2005, p. 12, grifo da autora), faz “[...] referência àquelas pessoas que saem das suas rotinas espaciais e temporais por um período de tempo determinado”. Neste contexto, a autora considera que tanto o deslocamento de indivíduos além das fronteiras municipais, estaduais ou nacionais, quanto o deslocamento de um bairro para o outro nas grandes cidades, podem ser consideradas atividades turísticas. Dessa maneira, o comum entre ambos deslocamentos, para além das fronteiras nacionais ou além das fronteiras do bairro de residência, estaria no "[...] estranhamento, no prazer e uma certa ansiedade diante do desconhecido e do novo".

Independente dos deslocamentos efetivados, a presença de imagens e imaginários se materializa no cotidiano dos turistas. A imagem acaba se formando à medida que os turistas, antes de se deslocarem para $\mathrm{o}$ novo lugar, já terão tido um contato prévio com o mesmo, visualmente falando, por meio de fotos em jornais e revistas, da TV, de páginas de internet e das mídias sociais. Já o imaginário se reafirma a partir dos sentimentos construídos em relação aos lugares, levando a caracterização de tais como "romântico", "bonito", "perigoso" (Gastal, 2005).

Em sua obra, Tuan (1980) analisa a percepção do ambiente físico a partir dos sentidos (olfato, visão, audição e paladar). A partir destas análises ele ressalta diversas questões, tais como a caracterização do homem como um ser visual, fazendo com que a visão se coloque como um dos sentidos mais importantes para a progressão humana. A partir do olhar, o homem capta informações mais precisas e detalhadas acerca do ambiente, se comparado a audição, porém, o poder de sensibilização em decorrência do que é ouvido é maior do que por aquilo que se vê, em muitos casos.

No que tange a percepção dos espaços, Tuan (1980, p. 4) classifica-o como uma “[...] resposta dos sentidos aos estímulos externos, como a atividade proposital, na qual certos fenômenos são claramente registrados, enquanto outros retrocedem para a sombra ou são bloqueados". À vista disso, fazendo uma análise mais circunscrita à figura do turista em sua avaliação do espaço turístico, fruto de sua percepção mais direta, ele, como visitante, apresenta uma avaliação essencialmente estética, se colocando como a visão de um estranho, julgando pela aparência mediante algum critério formalizado de beleza (Tuan, 1980).

O desejo do turista por estar e conhecer um dado lugar é alimentado a partir das excentricidades daquele espaço. Isso pode, em certa maneira, explicar o porquê de os turistas buscarem por algo que seja diferente de seu cotidiano, fazendo com que o turismo resulte “[...] de uma divisão binária básica entre o ordinário/ cotidiano e o extraordinário" (Urry, 2001, p. 28). Quanto mais distante e diferente um local turístico se 
apresentar em relação ao local de trabalho/cotidiano dos turistas, mais atraente se tornará ao olhar dos mesmos (Urry, 2001).

Os espaços turísticos se apresentam sob o viés da objetividade e subjetividade, fazendo com que os lugares exerçam uma atração nos turistas devido a presença de diversos equipamentos infraestruturais, que proporcionem uma boa experiência e estadia e/ou em função de condicionantes psíquicas, que envolvam questões intangíveis, que perpassam por sentimentos, sensações, memórias. Todas essas questões em conjunto contribuem para a constituição de imagens turísticas, resultado de processos perceptivos que se diferem de observador para observador.

No contexto da contemporaneidade, um dos meios mais interessantes de difusão de imagens e experiências perceptivas acerca dos espaços turísticos se apresentam no formato de dados textuais e imagéticos disponíveis nas mídias sociais, fazendo com que seja possível presenciar a construção do que seria denominado por Ferrari (2015) como a construção de uma narrativa digital, movente e plural.

Em se tratando da relação entre as plataformas interativas e os turistas, os mesmos ao compartilharem suas experiências e imagens da cidade visitada, também estariam contribuindo para a construção da imagem turística. O turista, nas palavras de Donaire e Gali (2011), mantém um papel proeminente na consolidação de destinos turísticos, atuando como legítimo construtor de imagens turísticas. Dessa forma, os turistas estariam incluídos em duas categorias, sendo elas: as de consumidores e de produtores de imagens, conforme adverte Gândara (2008).

As mídias sociais teriam um papel mediador e convergente no que se refere a construção de representações turísticas, ou seja, o turista se colocaria como um indivíduo ativo no processo de projeção de uma cidade e seus elementos, ao atribuir conotações qualitativas repletas de símbolos e signos em torno de uma atração. A sua percepção contribui para a construção de representações e narrativas, fazendo com que seja materializado também um imaginário acerca do lugar.

As fotos tiradas pelos turistas, assim como as informações textuais postadas, estão desempenhando um papel cada vez maior no processo de criação de imagens e narrativas acerca dos espaços, colaborando para a criação de estereótipos e incremento dos imaginários acerca do lugar (Donaire, Gali \& Royo, 2015).

\section{CONTEXTUALIZAÇÃO HISTÓRICA E ESPACIAL DE TIRADENTES: SUA ASPIRAÇÃO AO TÍTULO DE CIDADE PATRIMONIAL E TURÍSTICA}

A cidade de Tiradentes, fundada no século XVI, se caracteriza como um espaço remanescente do período colonial brasileiro, possuindo cerca de 7981 habitantes (Instituto Brasileiro de Geografia e Estatística [IBGE], 2019) e estando situada na Estrada Real, mais precisamente no Circuito Caminho dos Inconfidentes. A Estrada Real, construída em meados do século XVII, se caracteriza como a maior rota turística do país, se estendendo por mais de 1630 quilômetros e cruzando os estados de Minas Gerais, Rio de Janeiro e São Paulo.

Em se tratando de suas atividades turísticas, Tiradentes se inseriu no mapa do Turismo somente a partir das décadas de 70 e 80 , sendo "redescoberta" por um grupo de empresários. A partir desse momento, o casario, até então mal cuidado, mas íntegro, acabou por despertar o interesse de diversas pessoas externas à cidade, e que vislumbraram nela a possibilidade de angariarem lucros, passando a atuarem como co-atores responsáveis pelas transformações nas quais a cidade passou, e ainda continua a passar. Muitos empresários se mudaram para a cidade e investiram de modo intensivo em pousadas e restaurantes, a título de exemplo (Sousa \& Schicchi, 2017).

É importante destacar o papel da Rede Globo na divulgação de Tiradentes a nível nacional, mediante a figura do executivo Yve Alves, que realizou importantes projetos na cidade por meio da Fundação Roberto Marinho (Guimarães, 2010; Campos, 2012). Várias novelas foram gravadas na cidade, fazendo com que ficasse conhecida nacionalmente, sobretudo a partir da década de 1990. 
A cidade exibe um dos acervos arquitetônicos mais relevantes de Minas Gerais, formado por construções setecentistas religiosas, civis e oficiais. O patrimônio tombado pelo Instituto do Patrimônio Histórico e Artístico Nacional (IPHAN) em 1938 abrange, além das edificações coloniais, os mais distintos vestígios da forma de ocupação da cidade, revelando formas de subdivisão dos lotes, formação de quadras, áreas mais densas e outras de menor ocupação, bem como as áreas verdes próximas ao sítio urbano tradicional (IPHAN, 2020). De acordo com Neves e Castro (2020), a opção pelo tombamento como sítio histórico considerou o conjunto de edificações em sua totalidade, não restringindo apenas a bens isolados, impedindo uma descaracterização do conjunto e zelando pelas características coloniais.

A arquitetura da cidade se mostra singular, havendo uma representatividade da arquitetura religiosa, marcadamente, pelos estilos Barroco e Rococó. Ainda hoje, as igrejas funcionam como pontos de referência na paisagem urbana de Tiradentes, tal como era nos tempos coloniais (Oliveira \& Santos Filho, 2010). Do período do Barroco, tem-se como exemplar principal a Matriz de Santo Antônio, construída dentro dos padrões das grandes matrizes de Minas Gerais e possuindo uma rica ornamentação da nave e da capela-mor.

Em se tratando do fluxo de turistas na cidade, registra-se uma proporção de cerca de vinte e nove turistas para um morador, representando em torno de 232.000 mil turistas anualmente. Esse fluxo anual de turistas, decorre por motivos diversos, dentre eles a alta gastronomia, eventos culturais - numa média de um evento por mês - a arquitetura local e pesquisas/estudos.

Relativo aos eventos ocorridos em Tiradentes, a cidade realiza, de forma anual, dois grandes festivais que já se tornaram até a "marca" da cidade, sendo eles a Mostra de Cinema e o Festival Cultura e Gastronomia. Tais eventos foram concebidos para atrair o turista e organizados por empresas de fora da cidade. O festival de cinema, no ano de 2020, completou vinte e três edições e a cada ano a arquitetura temporária das instalações do evento têm ressignificado diversos espaços do centro histórico, articulando contemporaneidade e passado histórico (Neves \& Castro, 2020). Ambos os festivais, recebem em média 40.000 turistas cada um.

\section{RESULTADOS E DISCUSSÕES}

\subsection{O PATRIMÔNIO HISTÓRICO RELIGIOSO SOB A ÓTICA DOS TURISTAS DE TIRADENTES-MG}

Caberá neste tópico análises acerca da imaginabilidade dos elementos (Lynch, 1997), em se tratando do patrimônio histórico religioso de Tiradentes. Lynch (1997, p. 11) define o conceito de imaginabilidade como uma "[...] característica, num objeto físico, que lhe confere uma alta probabilidade de evocar uma imagem forte em qualquer observador dado [...]" sendo, "[...] aquela forma, cor ou disposição que facilita a criação de imagens mentais claramente identificadas". Em se tratando do processo construtivo, Lynch (1997) considera que uma imagem seria formada pelo conjunto de sensações experimentadas ao observar e viver em um dado local. Dessa maneira, as imagens derivam de uma relação entre o observador e o seu habitat, seu meio.

O patrimônio histórico religioso de Tiradentes encontra-se distribuído espacialmente em pontos diferentes da cidade, havendo uma concentração dos mesmos no centro histórico. Apenas um deles se encontra fora do centro, a Capela Santo Antônio do Canjica. O trabalho classifica este patrimônio a partir dos estudos de Lynch (1997) como os marcos, reiterando que

Os marcos se tornam mais fáceis de identificar e mais passíveis de ser escolhidos por sua importância quando possuem uma forma clara, isto é, se contrastam com o seu plano de fundo e se existe alguma proeminência em termos de sua localização espacial. O contraste entre figura e plano de fundo parece ser o fator principal (Lynch, 1997, p. 88).

Os marcos religiosos de Tiradentes carregam consigo uma história e trazem identidade à cidade. Dessa forma, serão abordadas inicialmente as Igrejas, passando pelo Santuário e por fim, as Capelas. Cada um destes marcos traz consigo uma conotação perceptiva diferente, conforme será constatado mais adiante. É singular 
mencionar também que os textos analisados a partir do TripAdvisor se colocariam como representações, se reportando a um olhar sobre o objeto.

A Igreja Matriz de Santo Antônio, datada de 1732 (Figuras 1 e 2), é considerada uma das obras primas da arquitetura barroca em Minas Gerais, chamando a atenção pela suntuosa decoração interior, possuindo uma riquíssima ornamentação da nave e da capela-mor. A edificação encontra-se situada em um local elevado da cidade, possuindo um frontispício largo, e destaque para a portada, de autoria do Aleijadinho. Tem-se destaque também para o órgão - confeccionado na cidade do Porto, em Portugal, e instalado em 1788 - o relógio da torre, e o relógio de sol em pedra sabão - confeccionado em 1785 é um dos ícones mais famosos da cidade (IPHAN, 2020).

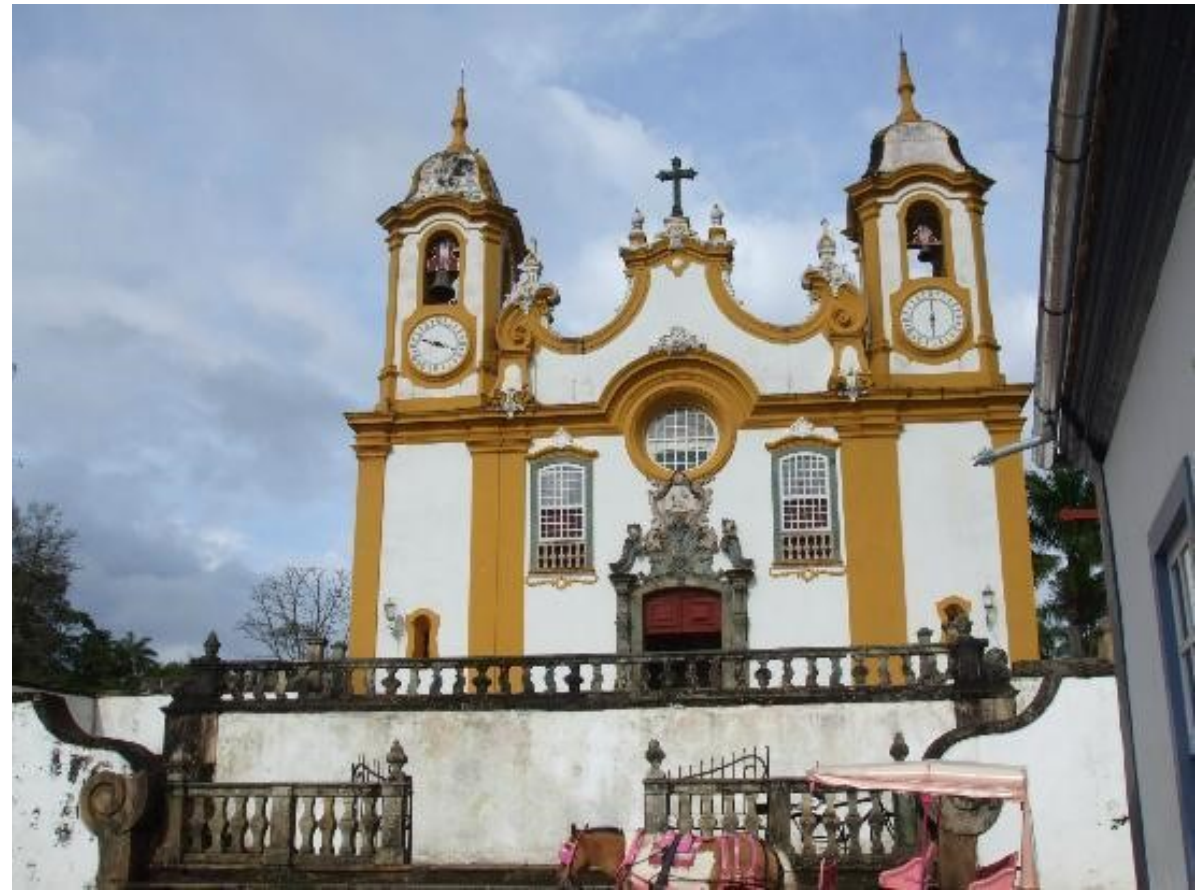

FIGURA 1

Vista da fachada da Igreja Matriz de Santo Antônio em Tiradentes - MG. Fonte: TripAdvisor (2020). 


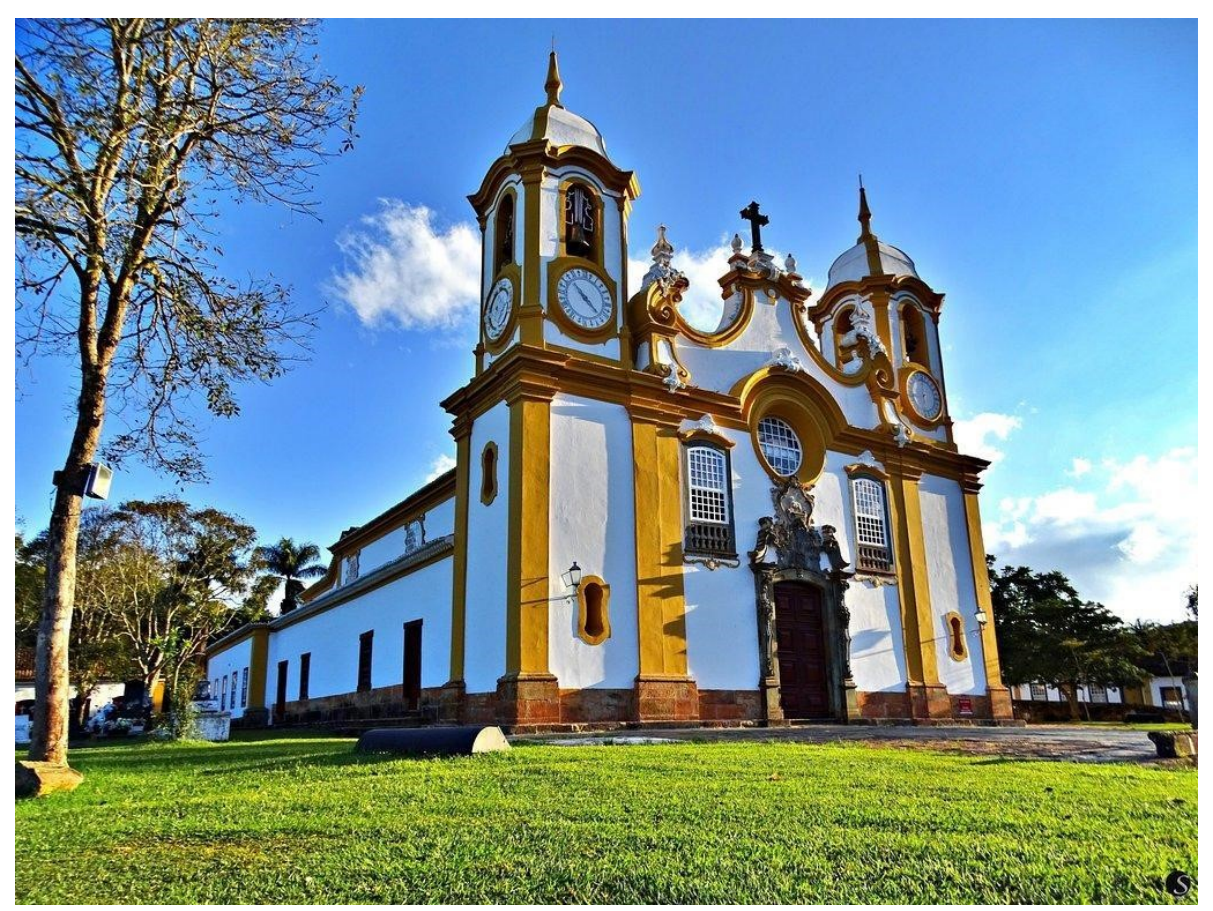

FIGURA 2.

Vista da fachada da Igreja Matriz de Santo Antônio em Tiradentes - MG. Fonte: TripAdvisor (2020).

Os turistas atribuem à igreja elementos diversos e a análise dos mesmos permite uma interpretação acerca de sua simbologia e percepção. De uma maneira geral, os turistas a nomeiam como "linda", "bonita", chamando a atenção para o seu interior, a partir dos atributos "dentro" e "interior". Em suas falas os turistas reafirmam que "vale a visita", e destacam os termos "vista" e as possibilidades de "tirar fotos". A figura do "guia" também é destacada, e acredita-se que tal fator atribui-se aos passeios de city tour ocorridos na cidade (Figura 3). Pressupõe-se que os comentários postados pelos turistas, e consequentemente a construção de sua percepção do local, possam ter uma relação direta com as histórias contadas pelos guias locais durante as visitas de city tour, ou até mesmo durante pesquisas que antecedem a viagem, reforçando a hipótese de que os turistas se colocam como consumidores e produtores de imagens (Gali \& Donaire, 2015; Gândara, 2008). Para Tuan (1975) a percepção se coloca não apenas como um registro perante a estímulos sensoriais, mas também um esforço imaginativo produzido mediante as necessidades do momento.

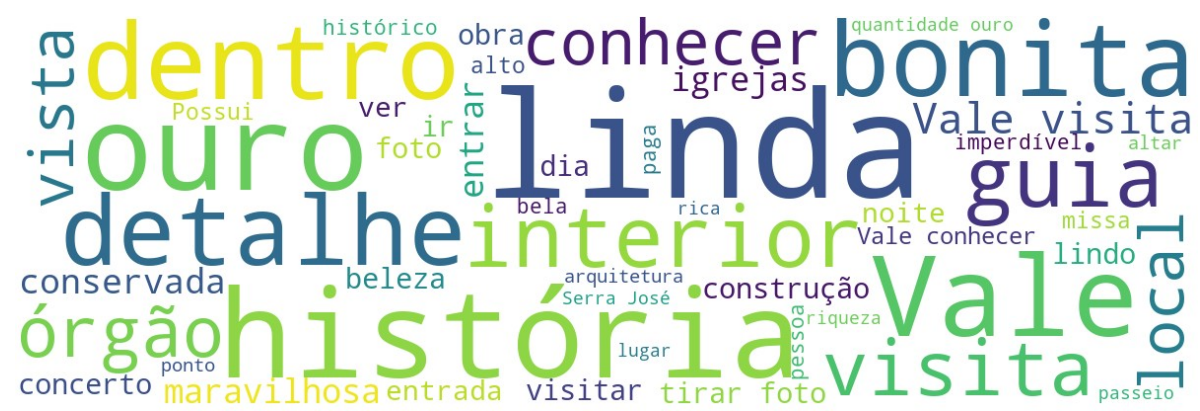

FIGURA 3.

Nuvem de palavras relativa a Igreja Matriz de Santo Antônio.

Fonte: Elaboração Própria a partir dos comentários abertos coletados no TripAdvisor (2020).

Um outro atributo em destaque seria "órgão", se remetendo ao importante órgão de tubos (instrumento musical) existente na igreja e a sua história. Trata-se de um dos mais preciosos instrumentos musicais 
remanescentes de Minas, tendo sido encomendado no período colonial, vindo de Portugal, desembarcado no Rio de Janeiro e trazido até Tiradentes por meio de animais de tração. O instrumento foi amplamente utilizado durante a efervescência musical do período barroco e acompanhando a liturgia e as celebrações familiares. Há destaque também para a menção "detalhes" e "ouro", que acredita-se que façam referência à riqueza de informaçôes (elementos decorativos) que a igreja apresenta e quantidade de ouro presente - sendo considerada a segunda igreja com maior quantidade de ouro do Brasil

No entanto, observa-se a ausência de referência à palavra "Aleijadinho", afinal trata-se do escultor/artista responsável pelas obras esculturais da fachada e um de seus mais expressivos trabalhos. Outro fator é a inexistência das menções à arquitetura barroca e rococó predominantes na composição física do espaço e que vão aparecer em comentários de outras igrejas, de arquitetura mais simples. Outro elemento de pouco destaque nos comentários seria a Serra de São José. De frente a matriz é possível ter vistas privilegiadas da Serra, se tornando até mesmo um cartão postal para fotos. Diferentemente das análises posteriores, aqui o turista não elege a Serra como um ponto de referência na descrição da edificação, soando como um possível descolamento da paisagem natural da construída em sua descrição e percepção.

No tocante à Igreja de Nossa Senhora do Rosário (Figuras 4 e 5), erguida entre 1740 e 1770, a mesma se apresenta em alvenaria de pedra, decoração em rococó e, no interior, pinturas em perspectivas barrocas (IPHAN, 2020). A localização desta construção se insere em uma das principais vias da cidade e do centro histórico, a Rua Direita, que abriga um imponente casario colonial e calçamento original, além de concentrar os principais restaurantes da cidade e a edificação no qual funcionou a Cadeia Pública no século XVIII - e hoje abriga um museu.

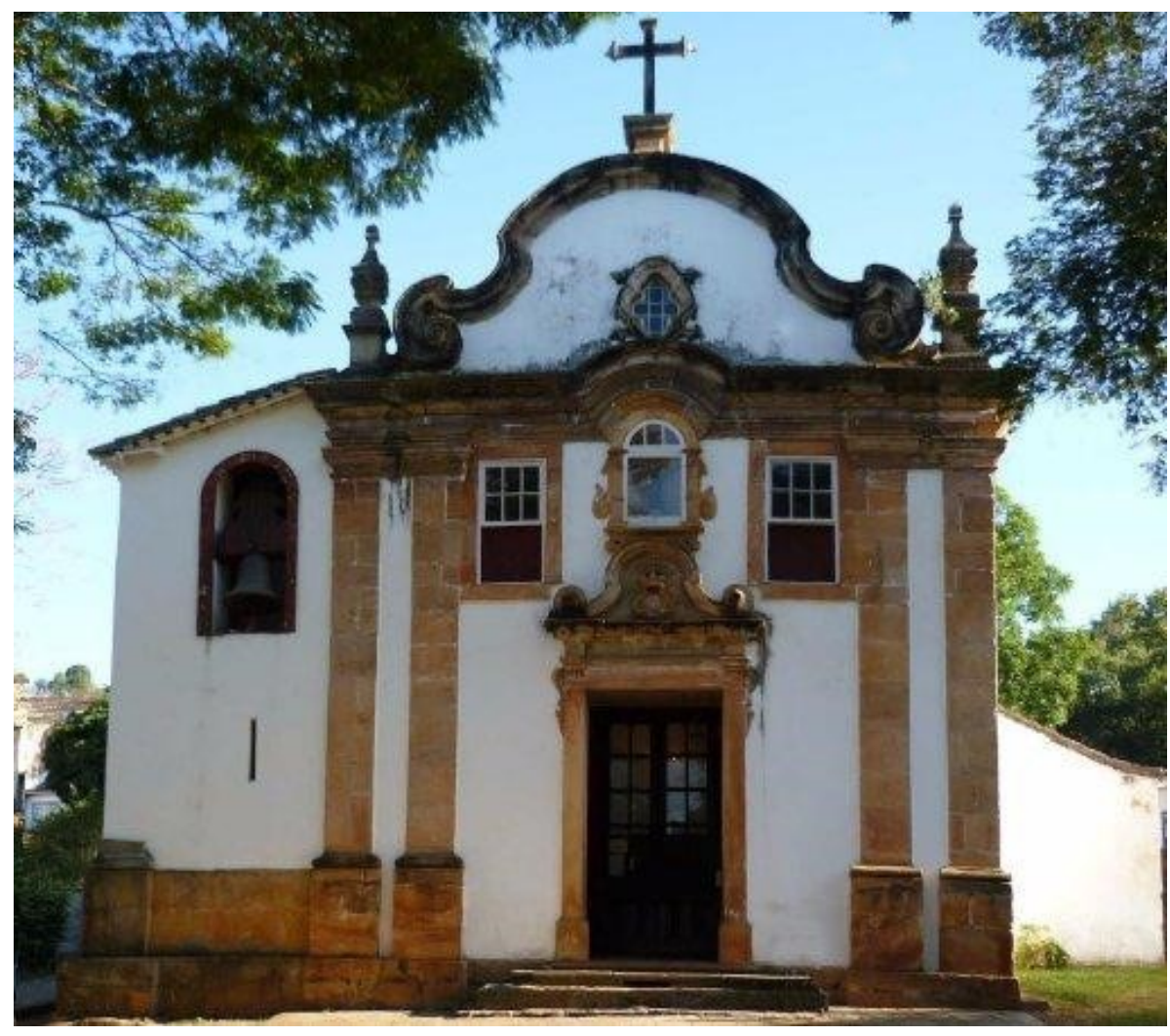

FIGURA 4

Vista da fachada da Igreja Nossa Senhora do Rosário em Tiradentes - MG. Fonte: TripAdvisor (2020). 


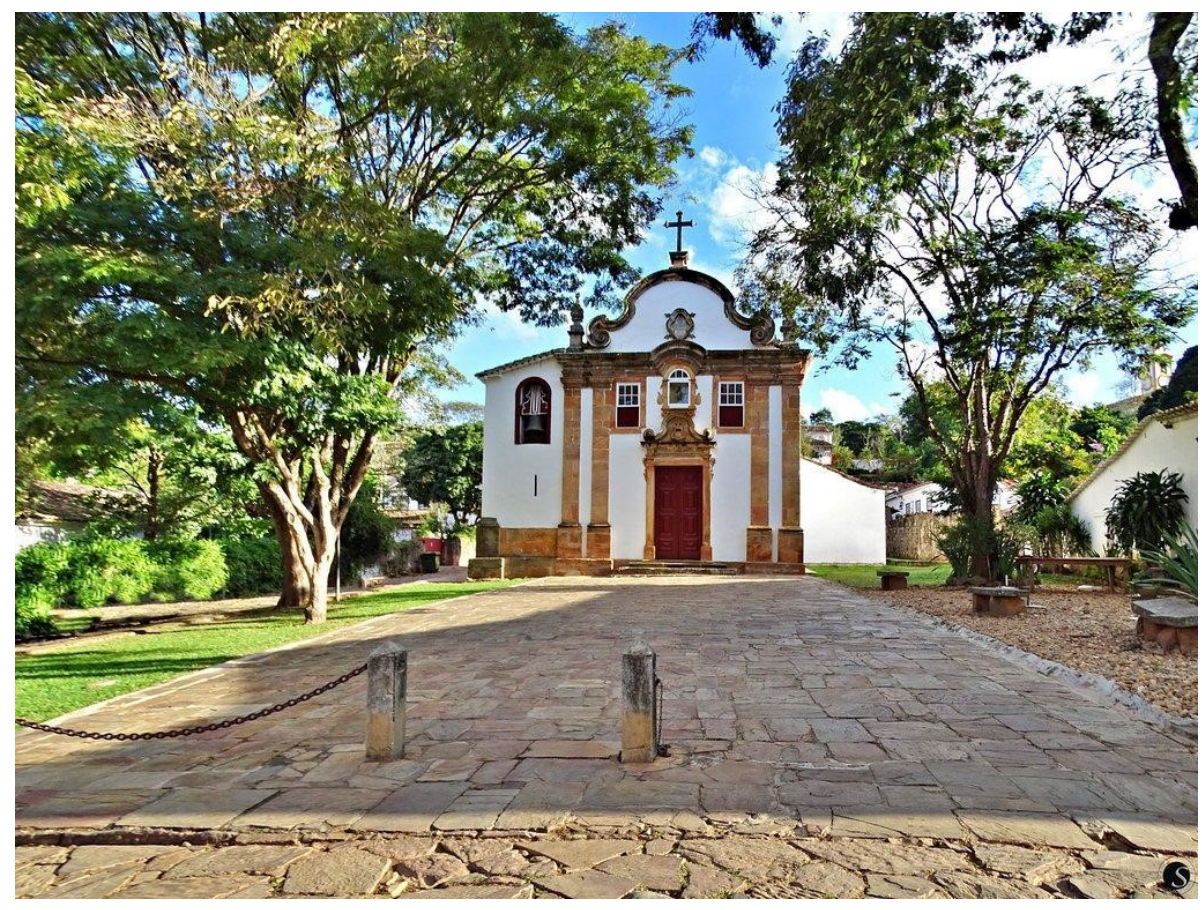

FIGURA 5

Vista da fachada da Igreja Nossa Senhora do Rosário em Tiradentes - MG. Fonte: TripAdvisor (2020).

Ao se analisar os comentários atribuídos à igreja (figura 6 e 7) foi possível notar uma diversificação de atributos, que em conjunto se remetem a "história", entendido aqui como um registro no tempo. Tal história, a partir dos atributos analisados, não se remete somente à edificação por si só, mas também ao trabalho escravo no qual foi recrutado para a sua construção. Esta percepção talvez seja reforçada por intermédio dos trabalhos dos guias locais, que ao percorrerem a cidade com os turistas contam um pouco da história das edificações mais emblemáticas do espaço da cidade e que, aos poucos, vão criando uma identidade histórica a cada elemento. Segundo Lynch (1997, p. 90) "quando uma história, um sinal ou significado vêm ligar-se a um objeto, aumenta o seu valor enquanto marco”.

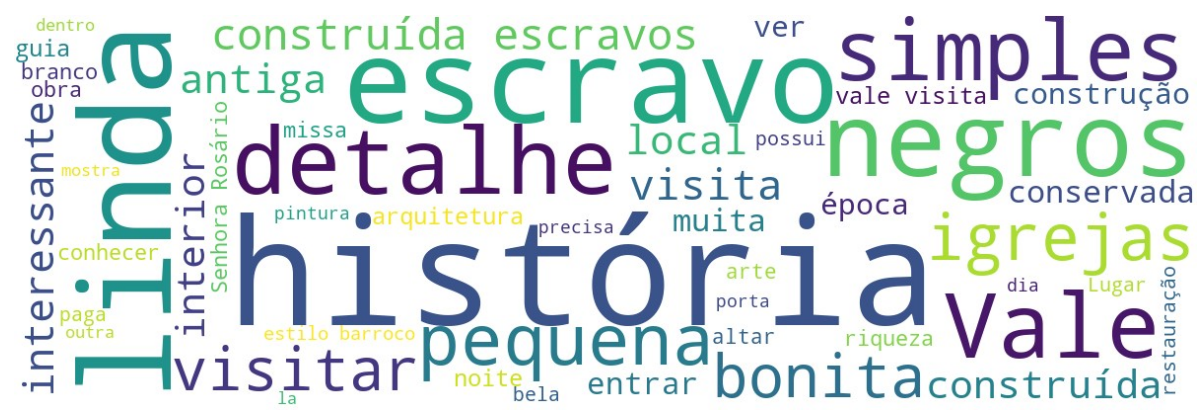

FIGURA 6.

Nuvem de palavras relativa a Igreja Nossa Senhora do Rosário.

Fonte: Elaboração Própria a partir dos comentários abertos coletados no TripAdvisor (2020)

Por outro lado, assim como na Igreja Matriz de Santo Antônio, não há expressividade a menção a atributos arquitetônicos e artísticos da construção. Dessa maneira, é possível notar que a assimilação que o turista faz da igreja acaba por levar em consideração, de forma mais direta, o contexto histórico no qual a mesma foi criada e não aos atributos arquitetônicos e artísticos envolvidos em sua criação. 
Posteriormente, tem-se o Santuário da Santíssima Trindade (figura 7 e 8), construída em estilo BarrocoRococó, datada do início do século XIX e que possui em seu acervo uma belíssima e rara imagem do Pai Eterno com Cristo crucificado e as imagens de Nossa Senhora das Dores e São José. Esta igreja está localizada um pouco mais distante do centro histórico, a cerca de 1,2 km do Largo das Forras - praça principal do centro. Ali acontece um evento tradicional na cidade, o Jubileu da Santíssima Trindade, sendo considerado o evento mais popular da cidade e com participação massiva da população local.

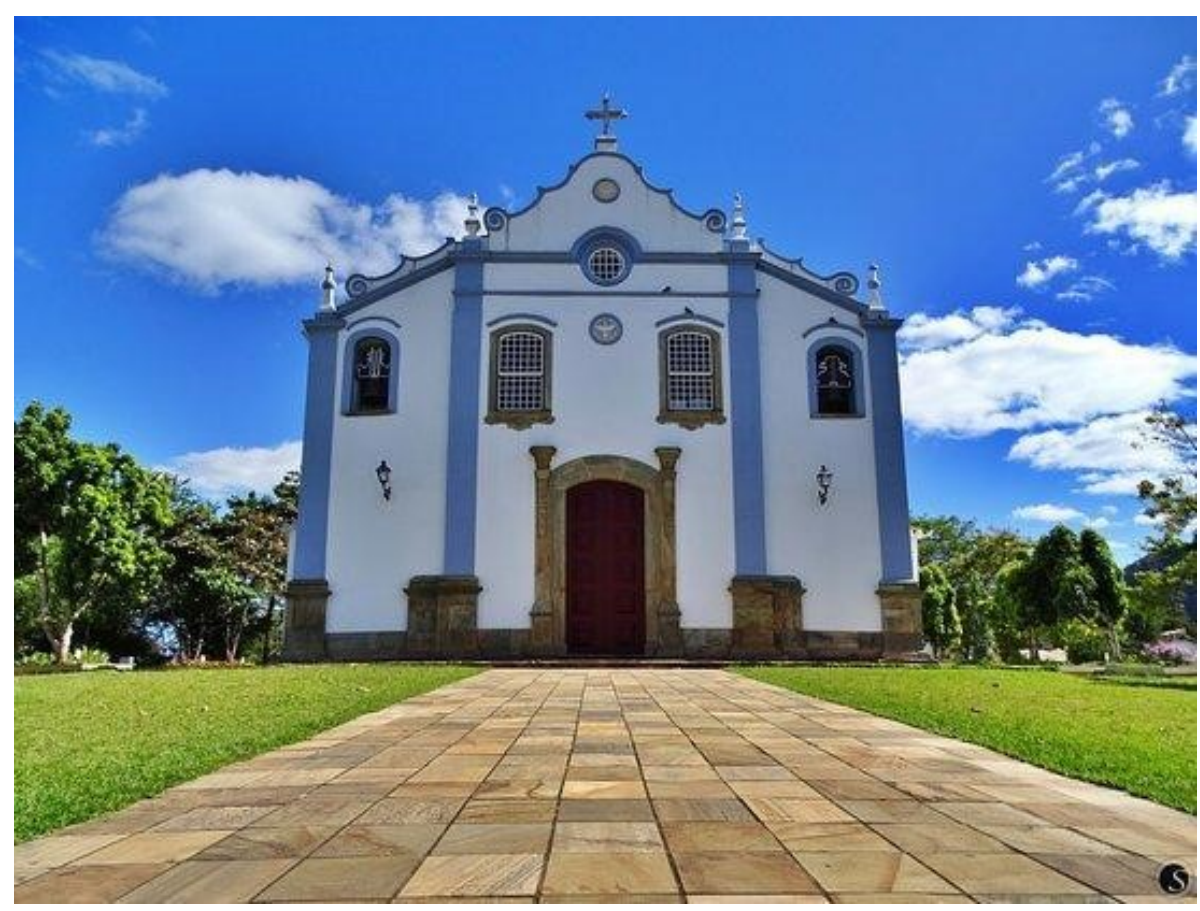

FIGURA 7

Vista da fachada do Santuário da Santíssima Trindade em Tiradentes - MG. Fonte: TripAdvisor (2020). 


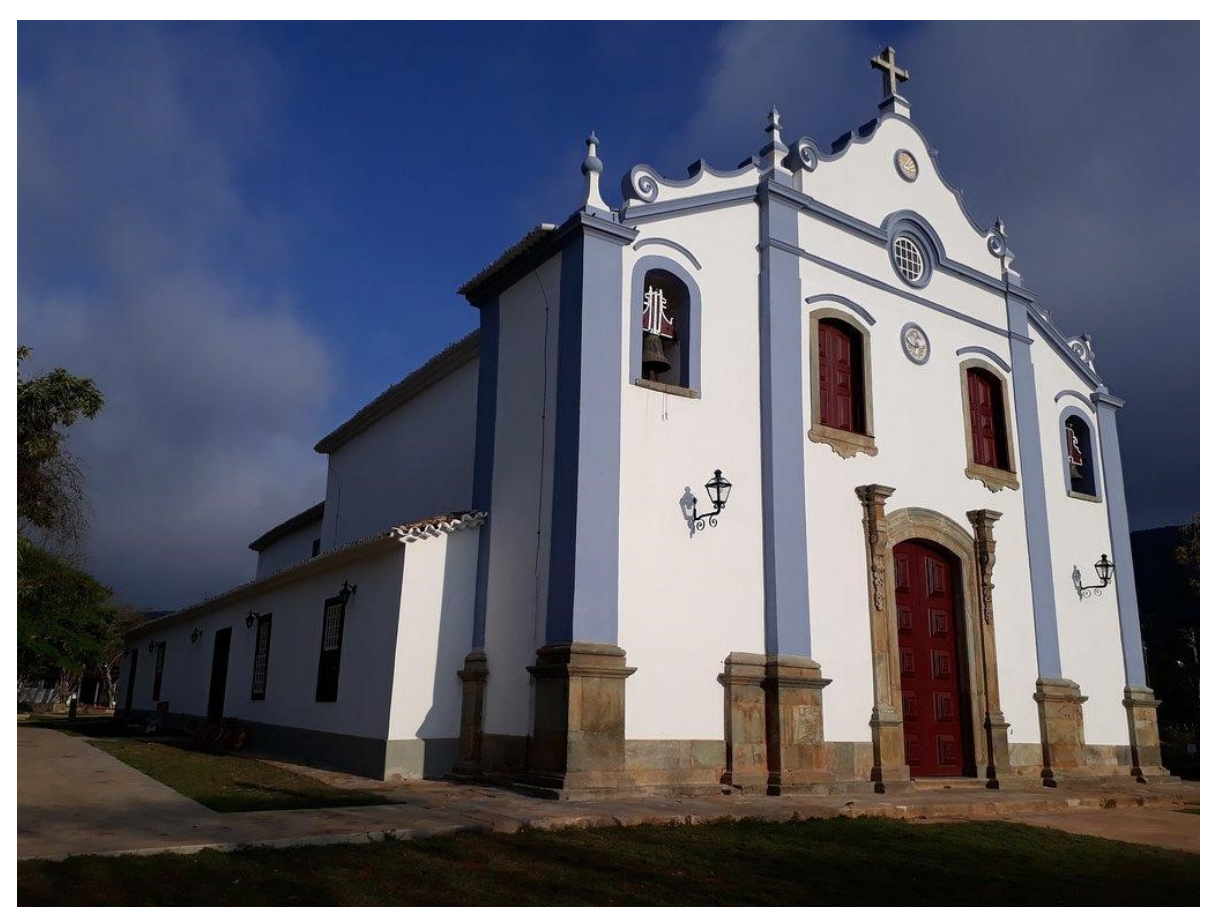

FIGURA 8.

Vista da fachada do Santuário da Santíssima Trindade em Tiradentes - MG. Fonte: TripAdvisor (2020).

Diferentemente das igrejas de Santo Antônio e Nossa Senhora do Rosário, mais expressivas no turismo da cidade, os turistas elegem atributos voltados ao estilo arquitetônico inspirado na construção da edificação, sendo eles "barroco" e "rococó", mesmo que de forma menos frequente se comparado a outros atributos. As "festas" também aparecem na qualificação, dado as festividades do Jubileu da Santíssima Trindade (Ver Figura 9). Mas de uma maneira geral, os turistas apreendem a simplicidade da fachada e de seus elementos, se comparada a outras edificações barrocas, mas mesmo assim a elegem como "bonita".

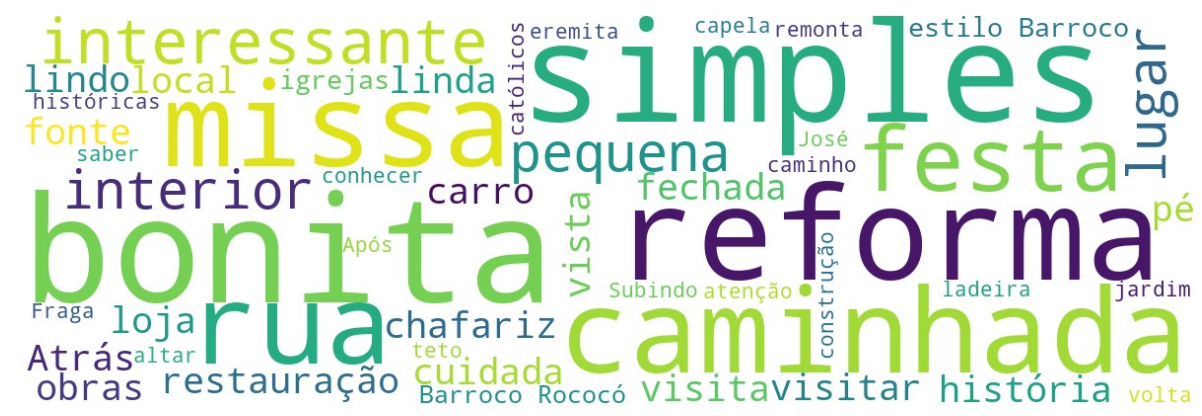

FIGURA 9

Nuvem de palavras relativa a Igreja Nossa Senhora do Rosário.

Fonte: Elaboração Própria a partir dos comentários abertos coletados no TripAdvisor (2020).

O entorno também é identificado pelos turistas, ao se remeter à "caminhada" e de forma menos frequente "ladeiras", "pé". O acesso ao Santuário se dá por meio de uma rua inclinada, a cerca de 650 metros da Matriz de Santo Antônio, e que permite observar diversos casarios no entorno.

Em se tratando das capelas, as análises iniciam-se com a Capela de São Francisco de Paula, datada de 1766 (Figuras 10 e 11), e que fica localizada no alto de uma colina, nas adjacências do centro histórico. De lá é possível avistar uma boa parte da cidade, de forma panorâmica, sendo o espaço muito utilizado pelos turistas para tirar fotos e apreciar o pôr do sol. A fachada da edificação se mostra relativamente simples, destoando das 
refinadas e robustas fachadas de outras igrejas, tais como a Matriz de Santo Antônio. A presença de fachadas mais simples em diversas igrejas de Tiradentes é explicada devido ao fato da maioria das igrejas pertenceram a irmandades pobres no século XVIII, inclusive a São Francisco de Paula.

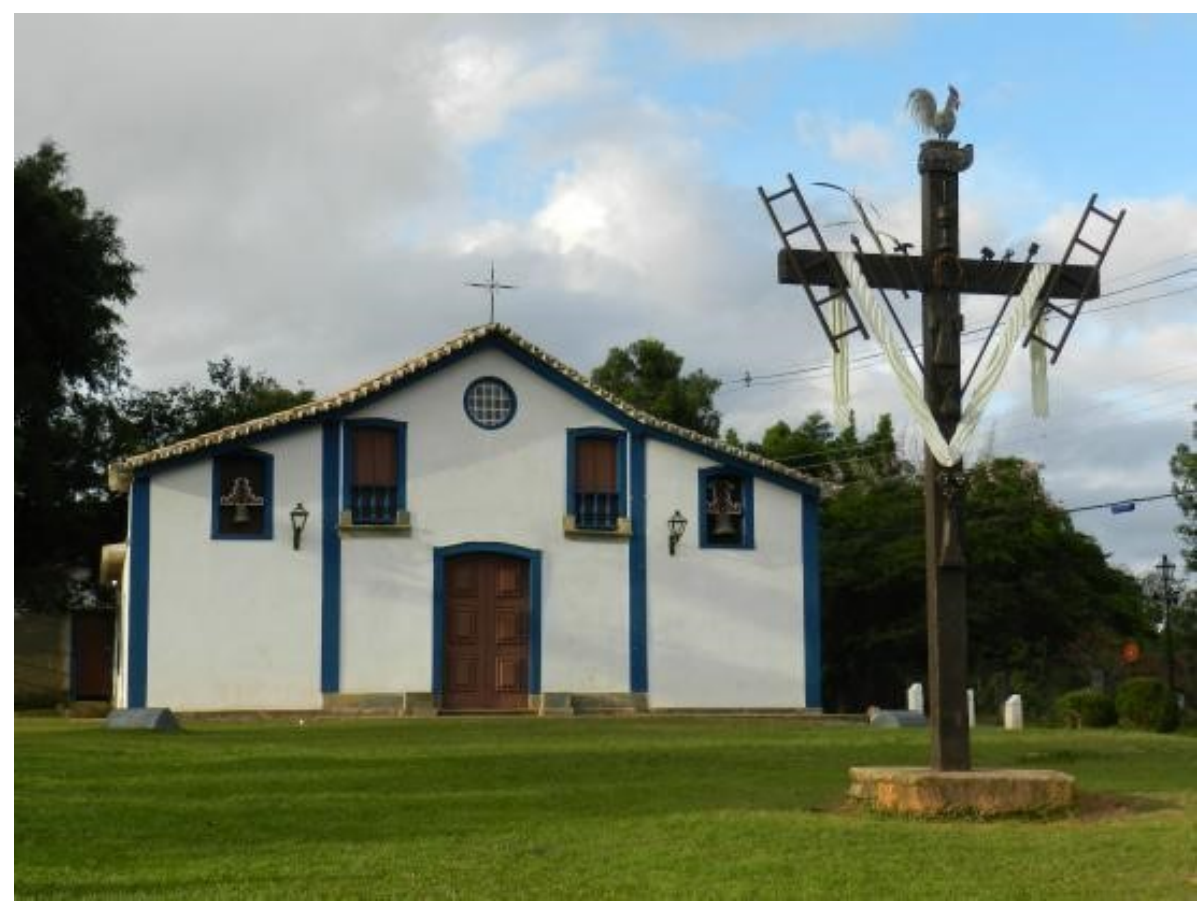

FIGURA 10

Vista da fachada da Capela São Francisco de Paula em Tiradentes - MG.

TripAdvisor (2020).

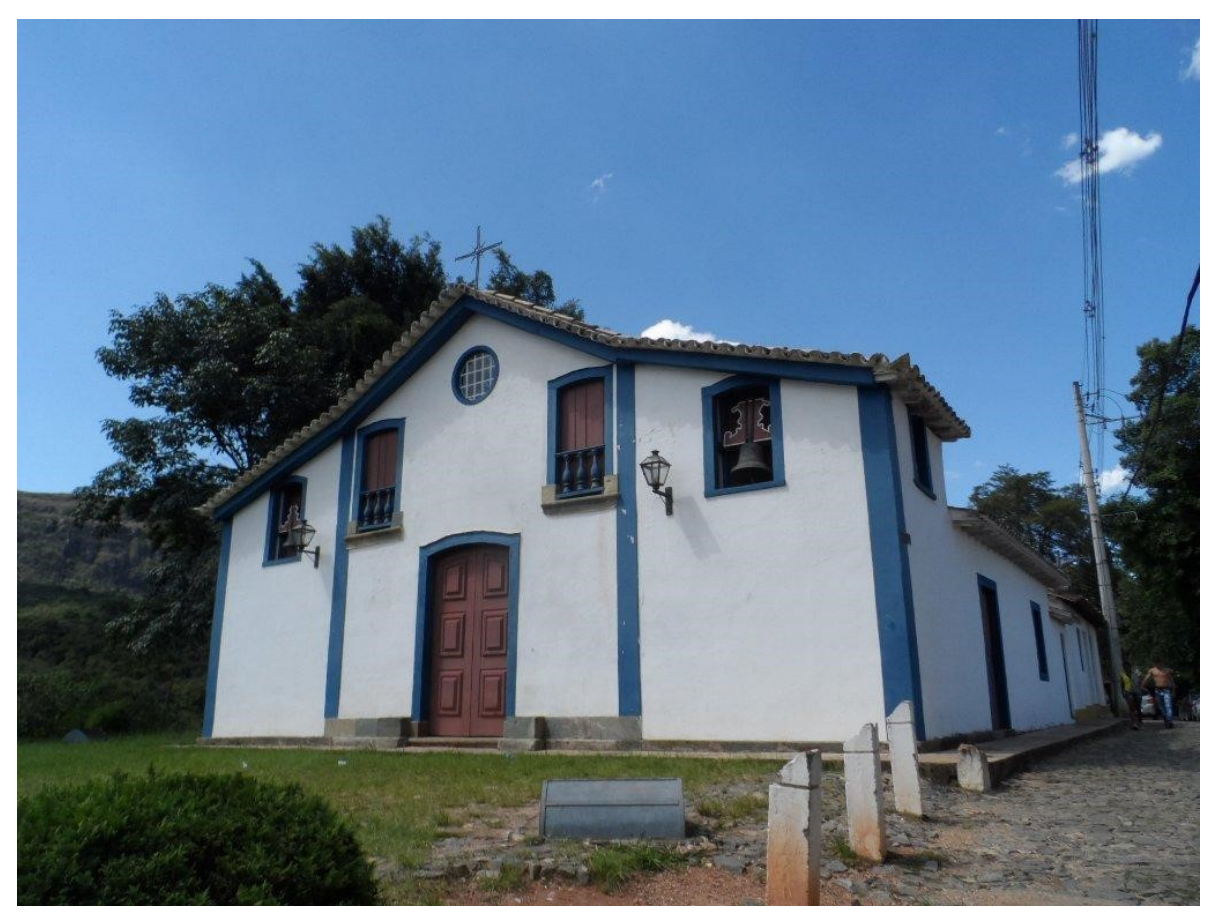

FIGURA 11

Vista da fachada da Capela São Francisco de Paula em Tiradentes - MG. Fonte: TripAdvisor (2020). 
A partir da análise referente aos elementos atribuídos a ela (Figura 12), foi possível notar que os turistas a assimilam não exatamente pela sua forma construída e seus elementos, como ocorre com o Santuário da Santíssima Trindade, mas sim a partir de sua relação com o entorno, ou seja, do espaço que é possível usufruir externamente, da paisagem do entorno. De acordo com Lynch (1997, p. 90), "a atividade associada a um elemento também pode transformá-lo num marco" e isso pode ser muito representativo a partir das denominações tais como "alto morro", "bela vista", "gramado", "pôr do sol", "mirante". Em se tratando da percepção quanto a capela, os atributos "simples", "pequena", "bela" e "fechada" são os mais expressivos.

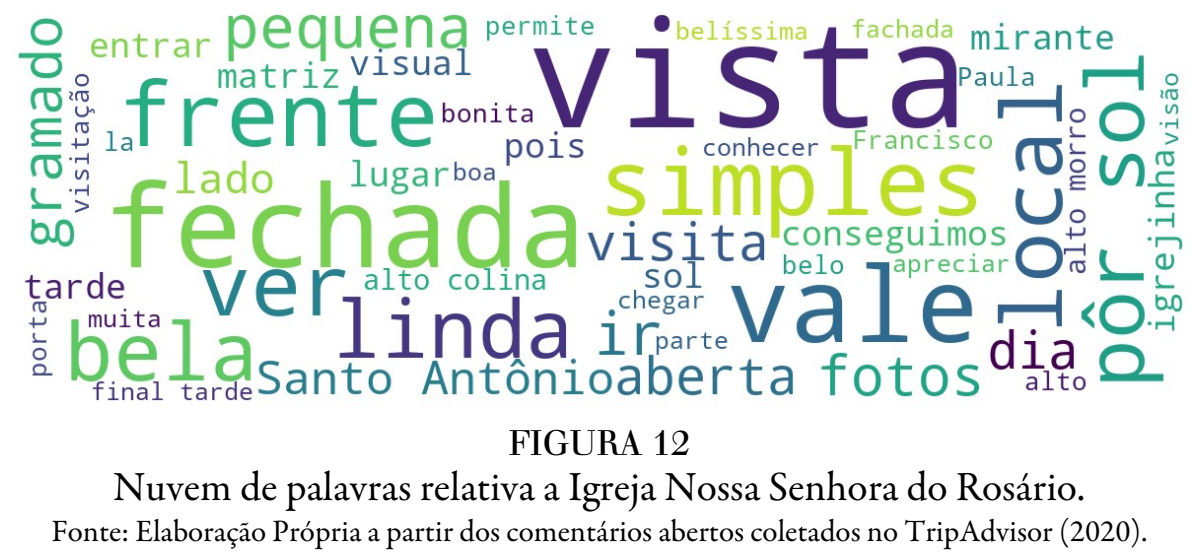

A capela está situada num dos pontos mais altos do centro histórico, permitindo uma visão panorâmica do mesmo, incluindo uma vista privilegiada da Matriz de Santo Antônio. É comum encontrar diversos turistas fotografando a paisagem nas adjacências da capela, assim como crianças brincando, piqueniques no gramado e apreciação do pôr do sol, se apresentando como um espaço de contemplação para o turista. De acordo com Urry (2001), quanto mais distante e diferente um local turístico se apresentar, em relação ao local de trabalho e cotidiano do turista, mais atraente se tornará ao olhar do turista. Afinal, “[...] os objetos potenciais do olhar do turista precisam ser diferentes de algum modo [...] situar-se fora daquilo é ordinário “ (Urry, 2001, p. 28).

Nos dizeres de Silva (2004), a percepção de um ambiente se coloca de forma mais apurada quando se trata de um lugar turístico, em que a paisagem se apresenta como um fator de atração. Por conseguinte, o turista passa a voltar a sua atenção para o aspecto visual dos lugares, estendendo-a para os elementos pitorescos, diferentes e mais atrativos aos sentidos, principalmente, aquilo que pode ser contemplado pelo olhar.

Em seguida tem-se as análises referentes à Capela de Nossa Senhora das Mercês (Figuras 13 e 14). A Irmandade de Nossa Senhora das Mercês foi instituída em 1756, tendo a construção da igreja parcialmente finalizada em 1807. O interior possui um rico altar-mor, de estilo rococó, possuindo diversas pinturas de artistas e peças de prata dos séculos XVIII e XIX (IPHAN, 2020). A capela está localizada na Praça das Mercês, compondo a delimitação do centro histórico. 


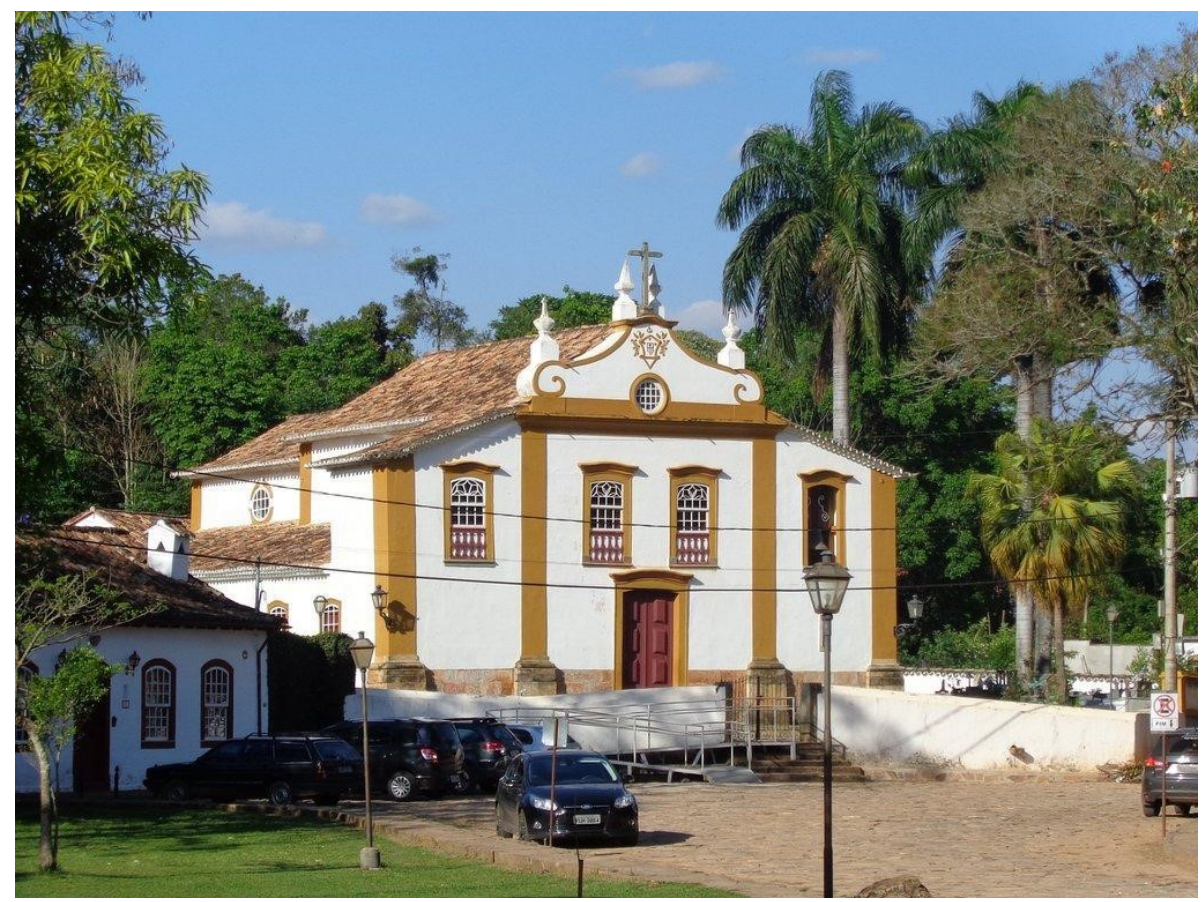

FIGURA 13

Vista da fachada da Capela Nossa Senhora da Mercês em Tiradentes - MG. Fonte: TripAdvisor (2020).

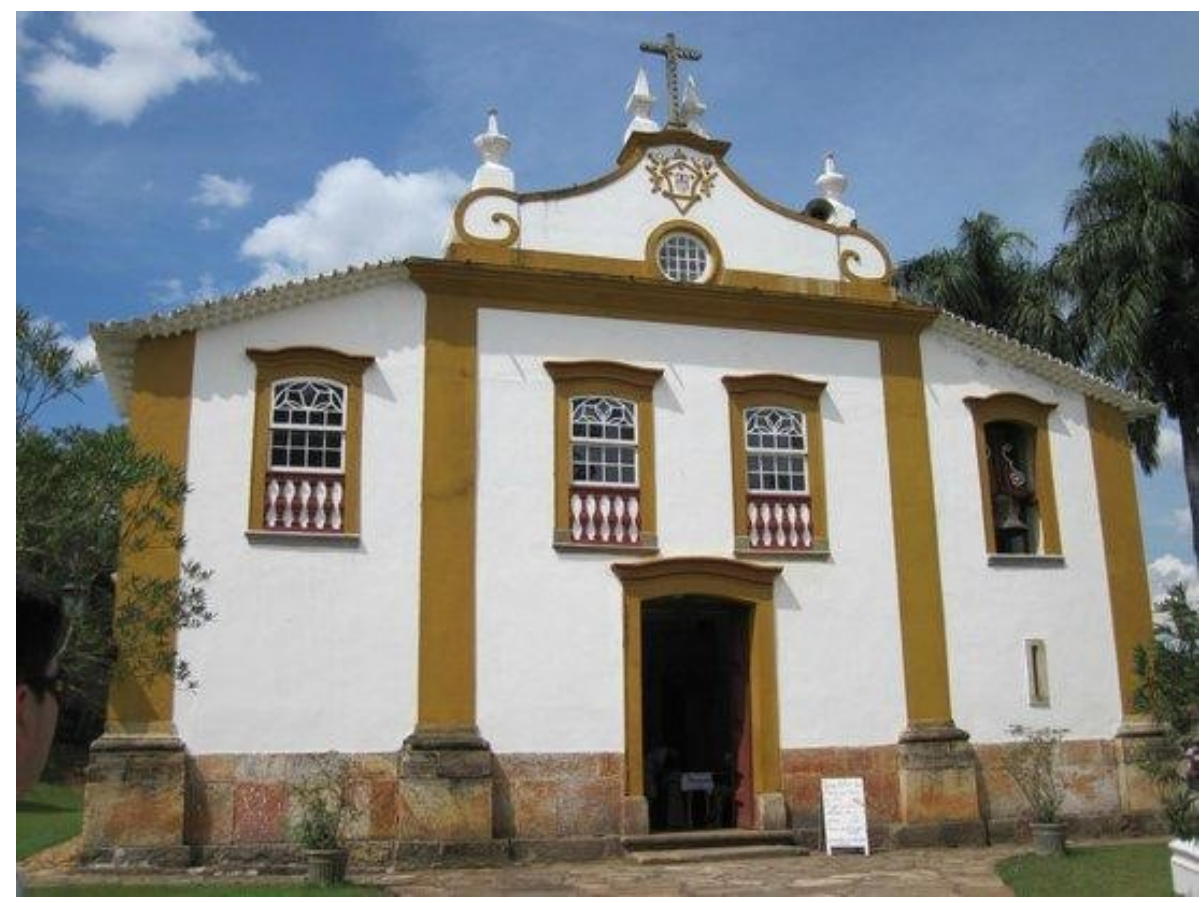

FIGURA 14

Vista da fachada da Capela Nossa Senhora da Mercês em Tiradentes - MG. Fonte: TripAdvisor (2020).

Os elementos que conformam a percepção do turista acerca da capela em destaque se resumem a "história”, "escravos", "linda/bonita", "simples” e "interior” (Figura 15). Há uma pequena observação dentre os comentários quanto ao estilo arquitetônico presente na edificação se referindo ao "rococó". Parece não ser uma edificação que chama a atenção dos turistas, a ponto de conformar uma identidade imagética da mesma. 
Talvez isso seja atribuído à própria localização da capela, fora do "roteiro" clássico de visitação ao centro histórico da cidade e distante da rota comercial e de serviços. O entorno da capela é formado por jardins e espaços de descanso e em épocas de carnaval é o ponto de encontro de vários blocos. Mas a paisagem exterior não é ressaltada pelo turista da mesma maneira que a paisagem da capela de São Francisco, ressaltando-se apenas a presença do "cemitério" ao lado da edificação. Acredita-se que o olhar do turista para esta localidade não tenha alcançado o extraordinário, conforme aponta Urry (2001).

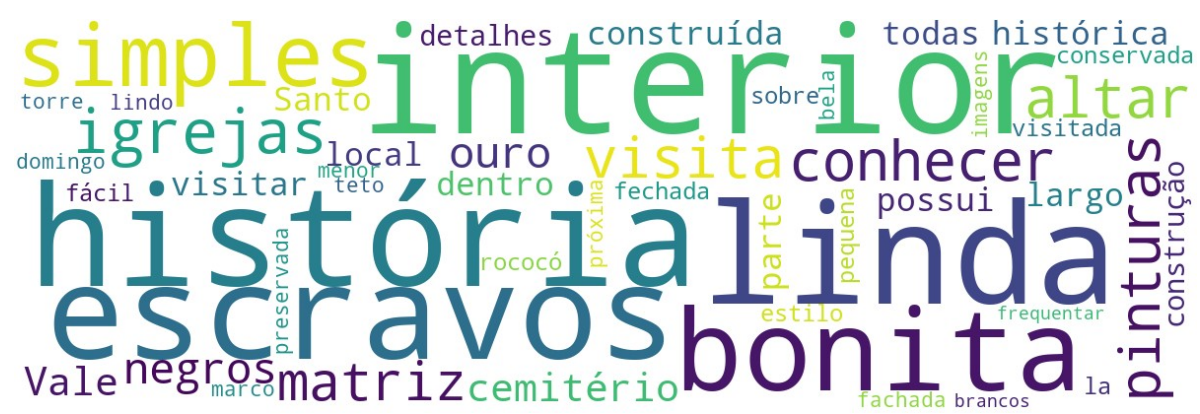

FIGURA 15

Nuvem de palavras relativa a Capela Nossa Senhora das Mercês.

Fonte: Elaboração Própria a partir dos comentários abertos coletados no TripAdvisor (2020).

Adiante, tem-se a Igreja São João Evangelista, localizada na rua Padre Toledo (Figuras 16 e 17). Diante da inexistência de documentação, há pouquíssimas informações a respeito da construção da capela, sabendose apenas que a Irmandade de São João Evangelista dos Homens Pardos foi fundada por volta de 1740 e a construção da igreja iniciada entre 1750/60 com recursos provenientes dos membros da irmandade. Em seu interior possui diversas pinturas em estilo rococó (IPHAN, 2020). 


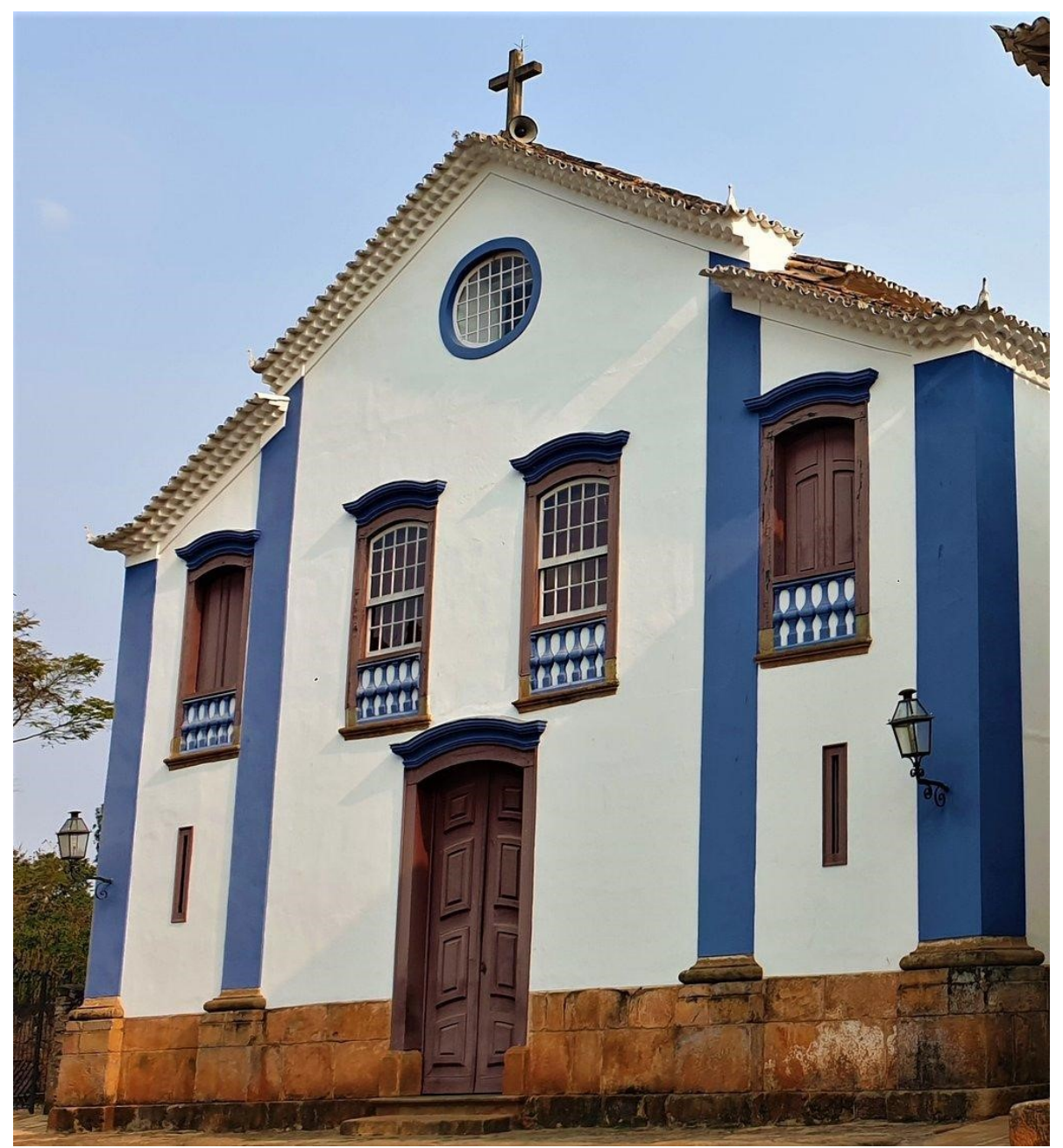

FIGURA 16

Vista da fachada da Igreja São João Evangelista em Tiradentes - MG. Fonte: TripAdvisor(2020). 


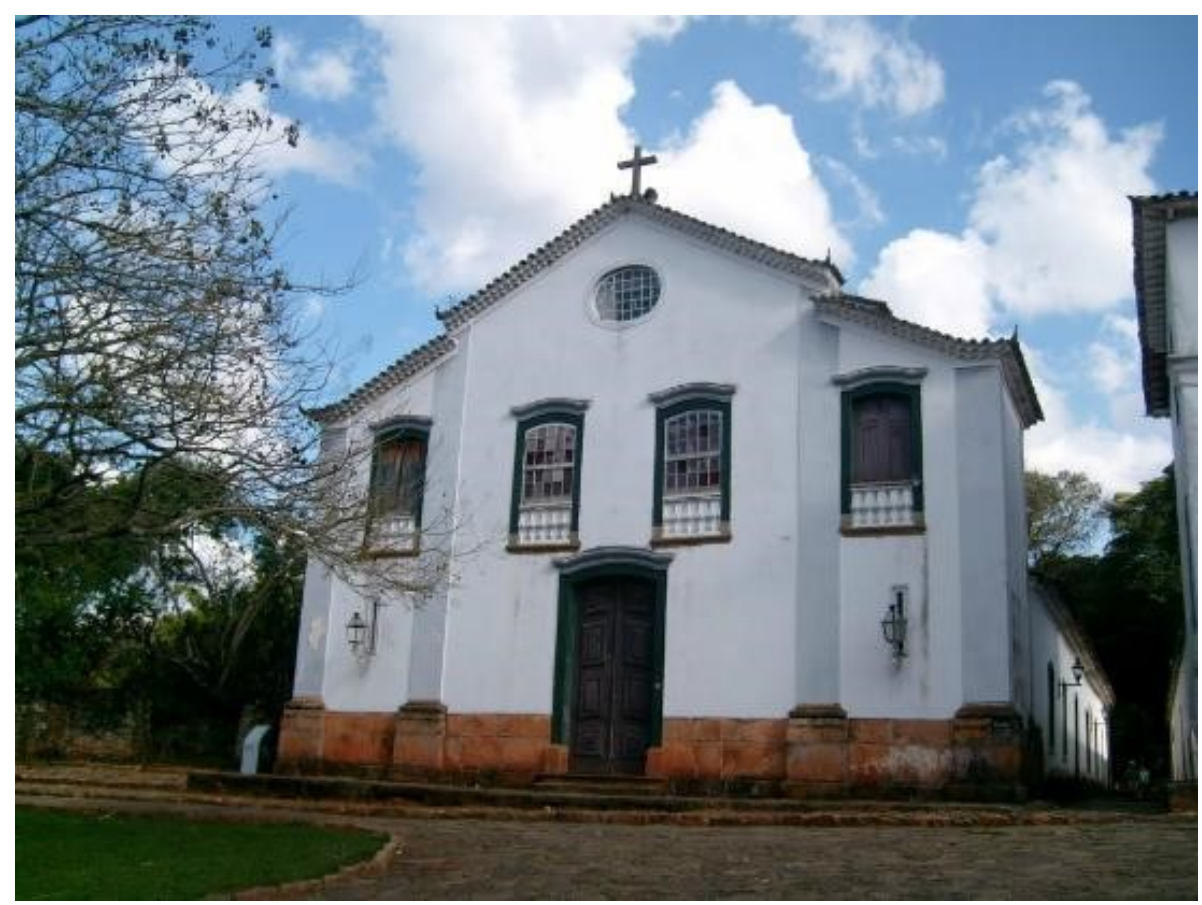

FIGURA 17

Vista da fachada da Igreja São João Evangelista em Tiradentes - MG. Fonte: TripAdvisor (2020).

Um dos principais atributos que caracterizariam a igreja, na concepção dos turistas, seriam "simples", "simplicidade", "história" (Figura 18). Acredita-se que os atributos de simplicidade façam menção a própria arquitetura da igreja, de fachada singela, uma marca de algumas igrejas e capelas de Tiradentes, com exceção da Igreja de Santo Antônio, tendo em vista que, muitas destas edificações pertenceram a irmandades pobres, conforme já mencionado. Nesta edificação o turista elege também um ponto de referência ao descrever a localização da igreja, que seria o Museu Padre Toledo, que fica ao lado da edificação

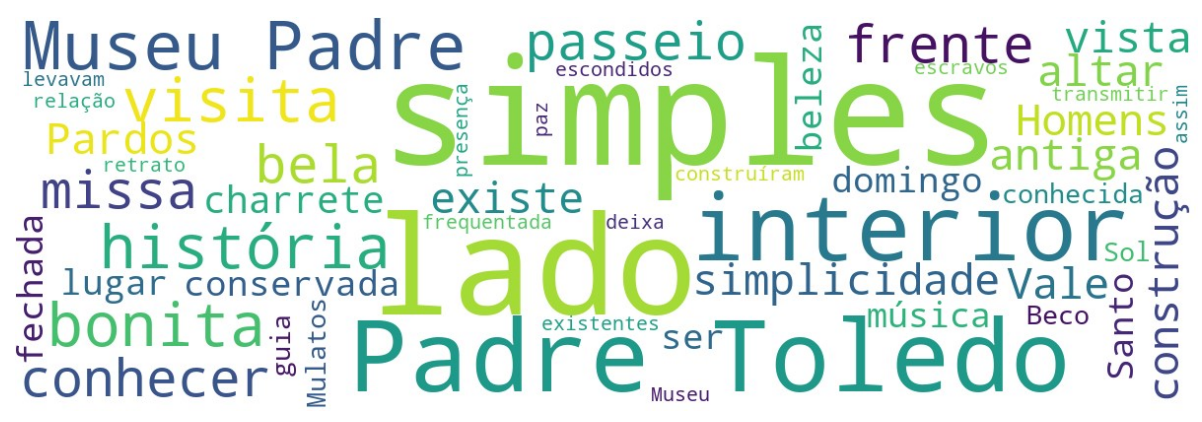

FIGURA 18

Nuvem de palavras relativa a Igreja São João Evangelista.

Fonte: Elaboração Própria a partir dos comentários abertos coletados no TripAdvisor (2020).

Em se tratando da Capela do Bom Jesus da Pobreza (Figura 19), a mesma encontra-se localizada no Largo das Forras - principal praça no centro histórico - e apresenta uma documentação muito escassa, dificultando a reconstituição histórica do monumento. Acredita-se que a capela tenha sido construída em 1786 e apresenta uma fachada e decoração interior bem singelos (IPHAN, 2020). 


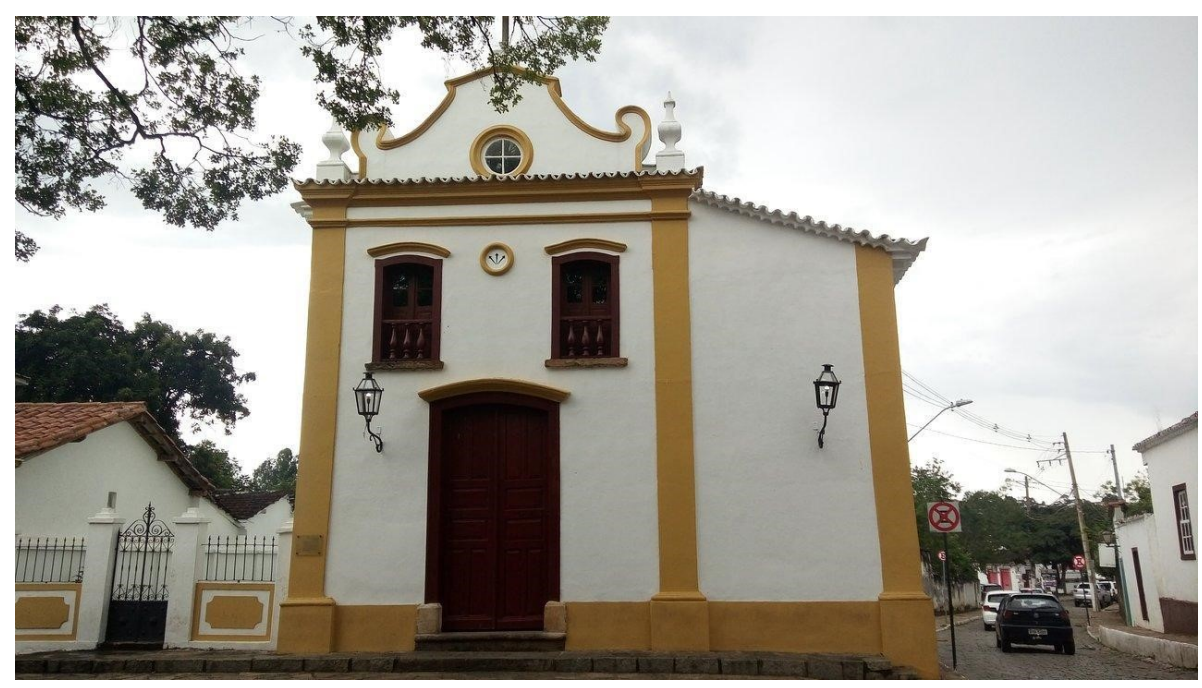

FIGURA 19

Vista da fachada da Capela do Bom Jesus da Pobreza em Tiradentes - MG. Fonte: TripAdvisor (2020).

Em questões de números, foram poucos os comentários obtidos para esta capela, se comparado às demais instituições religiosas analisadas, mas mesmo assim, é possível visualizar uma concepção geral a respeito da capela (Figura 20). As caracterizações "simples”, "estilo barroco”, "pequena” aparecem com frequência. É interessante notar que, diferentemente da Igreja de Santo Antônio - uma das mais representativas da cidade, em termos de turismo - aqui, mesmo diante de uma expressividade de comentários relativamente menor, os estilos arquitetônicos e culturais são lembrados e mencionados.

Os atributos "forras", "largo" e "praça" remetem-se à localização da capela, na praça principal do centro histórico, denominada Largo das Forras. É interessante notar como o turista também relaciona esta capela com o seu entorno, comparativamente a um ponto de referência no espaço. Como bem reforça Tuan (1980, p. 12) "os olhos exploram o campo visual e dele abstraem alguns objetos, pontos de interesse, perspectivas".

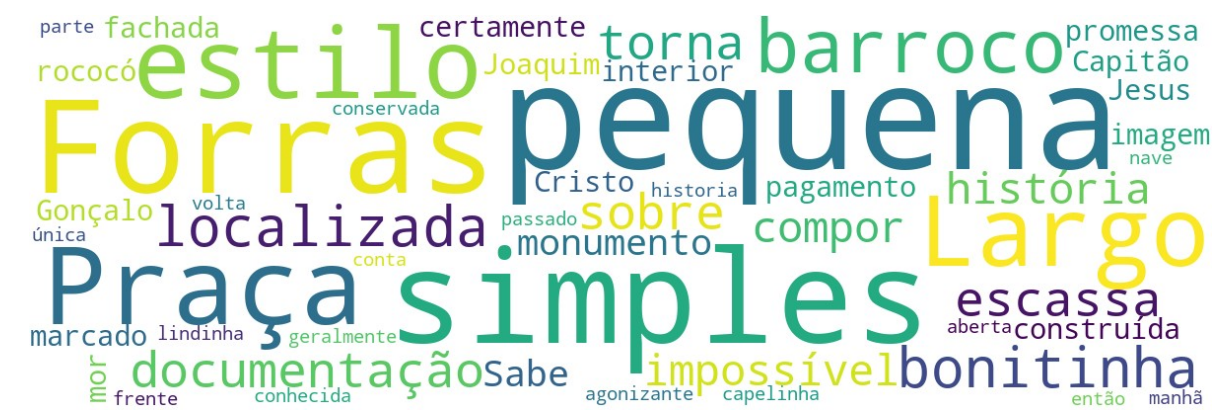

FIGURA 20

Nuvem de palavras relativa a Capela do Bom Jesus da Pobreza.

Fonte: Elaboração Própria a partir dos comentários abertos coletados no TripAdvisor (2020).

Uma outra capela com expressividade semelhante à do Bom Jesus dos Pobres, seria a Capela Santo Antônio do Canjica (Figura 21). A mesma não se encontra dentro dos limites do núcleo histórico de Tiradentes, mas é considerada pelo IPHAN como parte integrante do conjunto arquitetônico e paisagístico da cidade. Em registros consta-se que a construção da capela tenha se dado por volta de 1702 se localizando no bairro denominado Canjica. O bairro ganhou este nome pelo fato de terem sido encontradas pepitas de ouro do tamanho de uma canjica nesta localidade. No entanto, esta área não se consolidou como um arraial, se colocando apenas como um espaço de produção e como um polo secundário de atração da ocupação urbana. Isto pode explicar, em medida, a simplicidade em diversas construções nesta área, incluindo a Capela. A 
parte arquitetônica e decorativa da capela se apresenta extremamente simples, com um interior desprovido de altares.

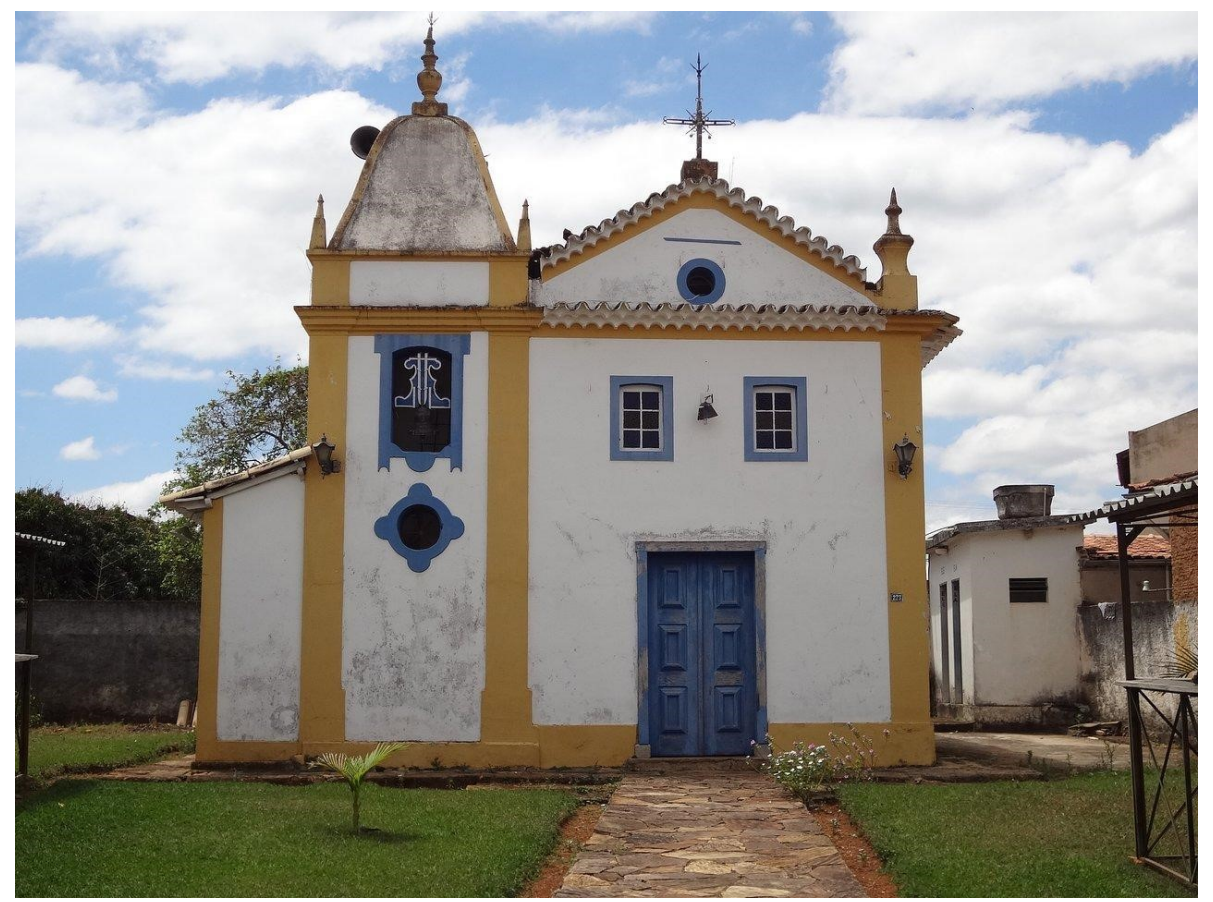

FIGURA 21

Vista da fachada da Capela Santo Antônio do Canjica em Tiradentes - MG. Fonte: TripAdvisor (2020).

O que mais chama a atenção ao analisar os elementos atribuídos a esta capela (Figura 22) é com relação a frequência da denominação "fechada", "ouro" e "paz". Acredita-se que a terminologia fechada se remeta a condição física da igreja, que em muitos momentos, pode se apresentar restrita a visitação e mais voltada a celebrações e uso da própria população local. Outra denominação, "ouro", poderia fazer menção ao período histórico do local e o processo de ocupação da área, e não necessariamente a presença de ouro na capela. De uma maneira geral, a mesma também é classificada a partir de suas características físicas, com denominações tais "pequena”, "simples", "bela”, "linda".

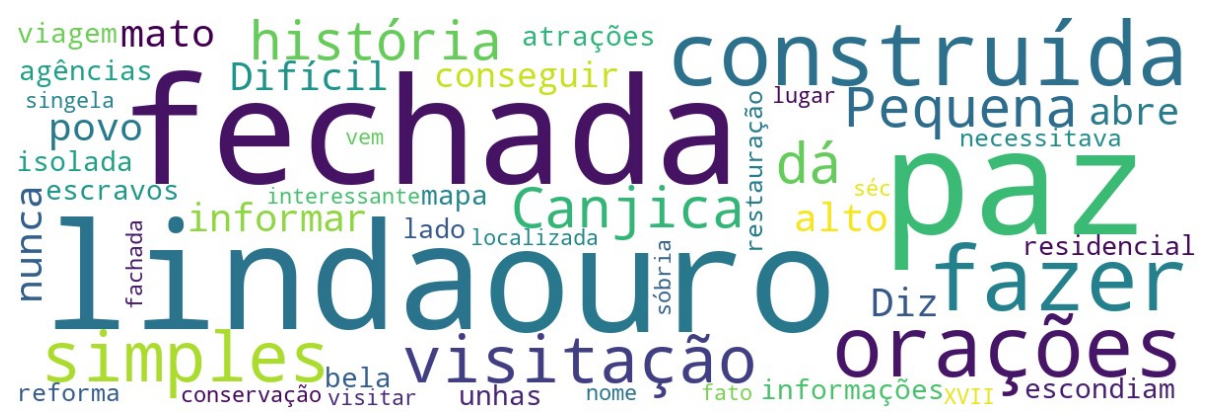

FIGURA 22

Nuvem de palavras relativa a Capela Santo Antônio do Canjica. Elaboração Própria a partir dos comentários abertos coletados no TripAdvisor (2020).

Ao analisar os atributos atribuídos aos marcos religiosos, nota-se que a imagem perceptiva atribuída aos mesmos tende a diferir em alguns pontos. De uma maneira geral, atributos tais como "linda", "bonita", "simples", "pequena" aparecem em diversos momentos, fazendo alusão ao próprio padrão construtivo de 
Tiradentes nos séculos XVI a XVIII. A maioria das igrejas da vila pertenceu a irmandades pobres e isso explica a simplicidade de algumas fachadas e interiores destituídos de grande quantidade de ouro.

Outro fator observado na análise, diz respeito à vinculação do marco religioso a um ponto de referência no espaço urbano, no momento em que o turista precisa caracterizar/descrever a edificação. Estes pontos de referência ora se apresentaram como elementos construídos, ora como elementos naturais. Em sua teoria, Lynch (1997) enfatiza que elementos visuais podem se tornar pontos de referência ou fatores de reconhecimento do usuário em se tratando do espaço da cidade.

Num contexto geral, os comentários e as percepções atribuídas aos marcos religiosos de Tiradentes, reafirmam a ideia de Lynch (1997) de que a criação de uma imagem se coloca de forma bilateral entre o observador e o observado. O que o observador enxerga é baseado na forma exterior, contudo, o modo como ele irá interpretar e organizar essas informações, e ainda como dirige a sua atenção, consequentemente irá afetar aquilo que ele vê. Grupos diferentes podem ter imagens também diferentes ou similares a respeito de uma mesma realidade exterior.

A imagem que é formada, nos dizeres de Silva (2004), implica na concepção mental apreendida e estabelecida pelo indivíduo, que acaba por imprimir nesta imagem seu conhecimento, suas avaliações e preferências acerca do ambiente em que vive. Da mesma maneira, a imagem formada pode ser resultado de uma questão cultural e coletiva, pois “[...] pessoas que compartilham situações similares no tempo e no espaço, expostas às mesmas experiências perceptivas, tendem a compor imagens mentais também semelhantes” (Silva, 2004, p. 2).

No caso de Tiradentes, e no caso particular dos seus marcos religiosos, os turistas apreende-os a partir de uma totalidade, mas em diversos momentos a representação que é projetada se apresenta de forma simplória, não estabelecendo, muitas vezes, vínculo com a cidade, e se colocando de forma fragmentada. $\mathrm{O}$ turista, ao observar um ambiente apresenta um ponto de vista, e sua percepção, de forma frequente, "[...] se reduz a usar os seus olhos para compor quadros" (Tuan, 1980, p. 72).

No entanto, vale reforçar que a avaliação que o visitante faz de um ambiente se coloca de forma estética, ou seja, se apresenta como a visão de um estranho, julgando-a apenas pela aparência, a partir de algum critério formal de beleza. Contudo, o julgamento deste visitante ainda apresenta certa importância, na medida em que o mesmo poderá contribuir baseado numa perspectiva nova, sendo capaz de notar méritos e defeitos de um de ambiente que já não se mostram mais visíveis aos residentes (Tuan, 1980).

\section{CONSIDERAÇÕES FINAIS}

As discussões apresentadas no tocante às possibilidades colocadas pelo uso de dados de mídias sociais, de técnicas de social media mining e o uso de softwares para text mining, revelam possibilidades abrangentes de estudos no que tange o campo do turismo e espaço urbano. Ao optar pela apresentação e visualização de dados nesse formato, foi possível notar alguns padrões de reconhecimento, a partir da repetição sistemática de algumas palavras.

No entanto, é preciso destacar que as informações contidas nas nuvens de palavras não irão responder por completo a um problema de pesquisa, de forma conclusiva e paradigmática, mas podem apontar caminhos para insights, estudos e percepções. Destaca-se também a facilidade de obtenção de dados nesta abordagem e uma coleta menos invasiva ao público alvo se comparado aos métodos presenciais. No entanto, não se trata de uma substituição completa dos dados tradicionais, mas uma complementação. Por ser um campo relativamente novo, ainda há muito a se estudar, mas acredita-se ser importante a divulgação de pesquisas na área, com o intuito de contribuir para o avanço científico e teórico a respeito do assunto.

Sabe-se que a plataforma do TripAdvisor se apresenta como um sítio onde o turista "avalia" a cidade e os atributos visitados, no entanto, acredita-se que os dados contidos revelam não apenas uma "experiência" ou a avaliação de um "produto" apenas, mas a percepção que o indivíduo tem do espaço visitado. Para a 
formulação de sua opinião, o indivíduo primeiro vivenciou o espaço, seja a partir do seu campo de visão e/ ou de outros sentidos, ou seja, teve um contato direto com a cidade, e a partir disso foi capaz de estabelecer ligações perceptivas que o motivaram e auxiliaram a emitir uma opinião.

De uma maneira geral, notou-se, a partir da análise dos dados virtuais, disparidades no tocante à percepção e imaginabilidade urbana a respeito dos principais marcos da cidade de Tiradentes, e como esta imagem é produzida e consumida em relação a um dado elemento turístico. Os dados apresentados e analisados se colocam como pertinentes aos estudos e discussões acerca da percepção urbana, se projetando também como um repertório visual relevante no tocante à imagem percebida e emitida pelos turistas. Dessa maneira, acredita-se que o artigo tenha cumprido o papel investigativo quanto a identificação da imagem perceptiva acerca dos marcos religiosos de Tiradentes mediante as impressões registradas no TripAdvisor.

O papel do turista frente a construção da imagem da cidade turística por intermédio das mídias sociais também foi trazida ao debate, notando-se uma construção de uma imagem dos marcos religiosos a partir da fala dos turistas. Dessa maneira, é possível associar a produção e difusão de informações nas mídias sociais a uma verdadeira narrativa turística digital, sendo alimentada diariamente e influenciando diretamente a forma de se perceber e consumir os elementos turísticos de um dado lugar.

Em algumas análises, foi possível notar que a percepção do turista acerca dos marcos religiosos se mostrou um pouco alheia aos atributos arquitetônicos da mesma. À vista disso, questiona-se, caso a cidade de Tiradentes não apresentasse elementos figurativos de destaque no turismo local, tais como a gastronomia, movimentos artísticos (artesanato) e grandes eventos, existindo apenas os marcos religiosos colocados pelo trabalho, ainda assim, a cidade se colocaria no mapa do turismo de Minas Gerais com tamanha expressividade?

\section{REFERÊNCIAS}

Amaral, F. (2016). Introdução a ciência dos dados: mineração de dados e Big Data. Editora Alta Books.

Campos, H. R. (2012). Espaço urbano e turismo em Tiradentes-MG. Revista Espaço Acadêmico, 132, 182 - 191. http ://periodicos.uem.br/ojs/index.php/EspacoAcademico/article/view/14935/9116

Cullen, G. (2015). Paisagem urbana. (Trad. Isabel Correia e Carlos de Macedo). $2^{\circ}$ ed. Edições 70.

Davidowitz, S. S. (2018). Todo mundo mente: o que a internet e os dados dizem sobre quem realmente somos. (Traduzido por Wendy Campos). Alta Books.

Donaire, J. A., Galí, N., \& Royo, V. M. (2015). El uso de GPS para el análisis del comportamiento espacio temporal de los turistas: pretest en el Valle de Boí. Cuadernos de Turismo. 35, 117 - 131. https://doi.org/10.6018/ turismo.35.221541.

Donaire, J. A., \& Galí, N. (2011) La imagen turística de Barcelona en la comunidad de Flickr. Cuadernos de Turismo, 27, 291-303. https://revistas.um.es/turismo/article/view/139961/125871

Ferrari, P. (2015). A força da mídia social. Estação das Letras e Cores.

Galí, N., \& Donaire, J. A. (2015). Tourists taking photographs: the long tail in tourists' perceived image of Barcelona, Current Issues in Tourism. https://www.tandfonline.com/doi/abs/10.1080/13683500.2015.1037255

Galí, N., \& Donaire, J. A. (2013). Direct observation as a methodology for effectively defining tourist behavior. https:// agrilifecdn.tamu.edu/ertr/files/2013/02/4-p14f.pdf

Gândara, J. M. G. (2008). A Imagem dos Destinos Turísticos Urbanos. Revista eletrônica de Turismo Cultural, Número Especial, 1-22. http://www.eca.usp.br/turismocultural/aimagem.pdf

Gastal, S. (2005). Turismo, imagens e imaginários. Aleph.

Guimarães, A. F. (2010). Construção e reconstrução de práticas culturais em Tiradentes MG: as relações entre turistas e nativos em uma cidade histórica mineira. [Dissertação de Mestrado em Gestão Social, Educação e Desenvolvimento Local]. Centro Universitário UMA. 
Karine de Almeida Paula, et al. Percepção dos turistas frente ao patrimônio histórico cultural: an...

IBGE. Instituto Brasileiro de Geografia e Estatística. Tiradentes. (2019). https://cidades.ibge.gov.br/brasil/mg/tirad entes/panorama

IPHAN. (2020). Instituto do Patrimônio Histórico e Artístico Nacional. http://portal.iphan.gov.br/

Lynch, K. (1997). A imagem da cidade. Martins Fontes.

Neves, C. O., \& Castro, M. L. A. C. (2020). Mostra de cinema de Tiradentes: a arquitetura efêmera como protagonista da identidade contemporânea. Caderno Virtual de Turismo, 20(1). https://doi.org/10.18472/cvt.20n1.2020.1 703.

Oliveira, M. A. R., \& Santos Filho, O. R. (2010). Barroco e Rococó nas igrejas de São João del-Rei e Tiradentes. Brasília: IPHAN, Programa Monumenta. http://portal.iphan.gov.br/uploads/publicacao/barroco_rococo_sjdelrei_tira dentes_vol_2.pdf

Recuero, R. (2018). Estudando discursos em mídia social: uma proposta metodológica. In T. Silva, J. Buckstegge, P. Rogedo. Estudando cultura e comunicação com mídias sociais. Editora IBPAD.

Severo, M. (2019) Tweets com geotags: ontem, hoje e amanhã. Disponivel em: https://www.martasevero.com/geotagg ed-tweets-yesterday-today-and-tomorrow/. [Consultado em: 14 de julho de 2019]

Silva, M.G. L. (2004). Cidades Turísticas: identidades e cenários de lazer. Aleph.

Sousa, D. S. \& Schicchi, M. C. S. (2017). O Centro Histórico de Tiradentes: turismo, urbanismo e patrimônio. [Apresentação de Trabalho]. I Congresso Nacional para Salvaguarda do Patrimônio Cultural, fronteiras do patrimônio, preservação como fortalecimento das identidades e da democracia, Cuiabá - MT.

Thomaz, G. M. \& Biz, A. A., \& Bettoni, E. M., \& Mendes Filho, L. (2016). Mineração de Conteúdo em Mídias Sociais: análise de conteúdos publicados por usuários sobre atrativos turísticos de Curitiba - PR. Marketing \& Tourism Review, 1(2). https://doi.org/10.29149/mtr.v1i2.3846.

Tuan, Y. (1980). Topofilia: um estudo da percep̧̧ão, atitudes e valores do meio ambiente (trad). DIFEL.

Tuan, Y. (1975). Images and mental maps. Annals of the association of american, 65(2). https://doi.org/10.1111/j.1 467-8306.1975.tb01031.x

TRIPADVISOR. (2020). Igrejas em Tiradentes. https://www.tripadvisor.com.br/Attractions-g737098-Activities-c 47-t175-Tiradentes_State_of_Minas_Gerais.html

Urry, J. (2001). O olhar do turista: lazer e viagens nas sociedades contemporâneas. Studio Nobel: SESC.

Zafarani, R., Abbasi, M. A., \& Liu, H. (2014). Social Media Mining: An Introduction. Cambridge University Press. h ttp://dmml.asu.edu/smm/chapters/SMM-ch1.pdf

\section{Notas}

[1] O TripAdvisor surgiu no ano 2000 se colocando como um guia de viagens onde os próprios turistas podem emitir opiniões, fazendo com que o site seja alimentado com relatos de experiência no formato de avaliações e comentários. A página possui mais de 600 milhões de avaliações e comentários redigidos, em sua maioria, por turistas (TripAdvisor, 2018). Esta plataforma se configura por possuir dados imagéticos e textuais e em grande quantidade, assim como o amplo acesso às avaliações 